\title{
THE Slings AND ARRows OF OUTRAgEOUS ForTune: CAN YOU “LOSE” THE LOTTERY BUT STILL WIN?
}

\author{
MARY J. SHARIFF* AND DARCY L. MACPHERSON**
}

This article discusses potential legal arguments that can be made for a lottery player in a seemingly hopeless situation: buying a winning lottery ticket immediately before the deadline, only to find out that the ticket was mistakenly dated for the next week's draw. Although the lottery rules and regulations and the courts' interpretation thereof are strongly slanted against lottery players, the authors nevertheless argue that a consistent and coherent application of traditional contract law principles could favour the claimant. They note that Canadian courts have rarely been consistent in their application of contract law to lottery situations, with courts sometimes characterizing lottery advertisements as both an offer and an invitation to treat. Even so, whether the lottery corporation is construed as the offeror or the offeree, the authors contend that a diligent analysis of the formation of the underlying contract could entitle the claimant to the prize. The article concludes that the regulatory framework governing lotteries does not necessarily preclude the acceptance of contract law arguments in favour of the claimant. Rather, it is the courts' tendency to analyze the contractual elements of the relationship between the player and the lottery corporation in a haphazard manner that has been the source of frustration for many lottery players across Canada.
Cet article porte sur des arguments juridiques potentiels que l'on pourrait faire valoir dans le cas d'une personne qui joue à la loterie qui semble être dans une situation désespérée : acheter un billet de loto gagnant juste avant la date limite et de constater ensuite que le billet portait par erreur la date du tirage de la semaine suivante. Bien que les règles et l'interprétation de la cour penchent fortement contre les joueurs de lotos, les auteurs font néanmoins valoir que si les principes du droit contractuel étaient appliqués de manière constante et cohérente, ils pourraient bénéficier le prestataire. Ils font remarquer que les tribunaux canadiens ont rarement fait preuve de constance dans leur application du droit contractuel dans les cas de loto, les tribunaux caractérisant parfois la publicité pour le loto comme étant à la fois une offre et une invitation. Advenant le cas, qu'une loterie soit vue comme l'auteur ou le destinataire de l'offre, les auteurs estiment qu'une analyse diligente de la formation du contrat sousjacent pourrait rendre le prestataire admissible au prix. L'article conclut que le cadre réglementaire qui régit les loteries n'écarte pas nécessairement l'acceptation des arguments du droit contractuel en faveur du prestataire. C'est plutôt la tendance des tribunaux d'analyser les éléments contractuels de la relation entre le joueur et la loterie de manière un peu désordonnée qui a été la source de frustration pour beaucoup de personnes au Canada.

\section{TABLE OF CONTENTS}

I. INTRODUCTION . . . . . . . . . . . . . . . . . . . . . . . . . . . . . . . . . . 632

II. THE FACTS . . . . . . . . . . . . . . . . . . . . . . . . . . . . . . . . 635

III. LOTTERY CASE LAW . . . . . . . . . . . . . . . . . . . 637

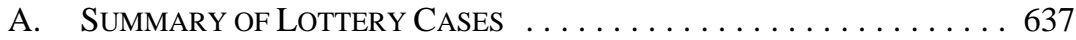

B. Summary of ReleVAnt PrinciPles $\ldots \ldots \ldots \ldots \ldots \ldots$. . . . . . 643

C. ARGUMENTS IN SUPPORT OF THE

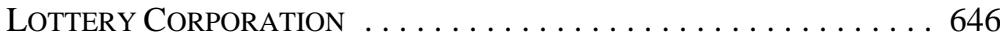

IV. ARgUMENTS IN SUPPORT OF THE LOTTERY PlAYER . . . . . . . . . . . 646

A. LOTTERY CORPORATION AS OFFEROR,

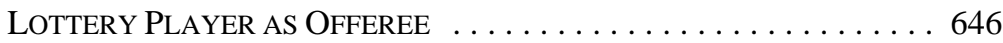

Assistant Professor, Faculty of Law, University of Manitoba; Research Associate, Desautels Centre for Private Enterprise and the Law. Thank you to student Christopher H. Bitonti whose research was made possible through the generosity of the Legal Research Institute of the University of Manitoba.

Associate Professor, Faculty of Law, University of Manitoba; Research Associate, Desautels Centre for Private Enterprise and the Law. 
B. LOTTERY CORPORATION AS OFFEREE,

LOTTERY PLAYER AS OFFEROR . . . . . . . . . . . . . . . . . . 662

V. AdDITIONAL CONSIDERATIONS . ...................6. 668

A. THE ELECTRONIC COMMERCE AND INFORMATION ACT _...... 668

B. The Technology Delay Does not Necessitate a

RESUlt in FAVOUR OF THE LOTTERY CORPORATION . . . . . . . . . 672

C. Policy Reasons Why the Claimant Should Win . . . . . . . . . 673

VI. CONCLUSION .................................. 678

\section{INTRODUCTION}

What if your lottery numbers came up for a $\$ 27$ million lottery jackpot, but your ticket was dated for the next week's draw? Would you think you had won? Probably not. But, what if you had asked the store clerk for a ticket for that night's jackpot before the 9:00 p.m. deadline? Would that make a difference? What if you had requested not one, but two tickets for that night's jackpot, and the first ticket printed bore the correct date - the date of that night's draw — but the second had the wrong date — the date of next week's draw? Should that make a difference? According to one lottery player, it should. This is exactly what happened to Joel Ifergan (the claimant) when he played Loto-Québec's Super 7 game in May $2008 .^{1}$

For the claimant, however, the odds of receiving a share of the jackpot appear stacked against him. This is because the regulations governing lottery games and the case law interpreting them almost always favour the lottery corporation. In order to be considered a winner, according to typical lottery regulations, the player must prove to the corporation that he is a winner. Most often, this will require strict proof, that is, the printed ticket must correspond precisely to the numbers drawn for a particular date. Of course, this is something that the claimant will not able to achieve, given that he does not possess such a ticket.

Under traditional principles of contract law, however, there are additional arguments that can be made that could very well convince a court that the claimant (and other players who have found themselves in similarly fantastic circumstances) should win the lottery, despite the fact that he does not hold a "winning" ticket according to the rules and regulations of the lottery corporation. An exploration of these potential common law arguments has utility despite the courts' implicit suggestion that the lottery regulatory framework is comprehensive. Indeed, many of the lottery ticket dispute cases also invoke common law contractual principles to supplement provincial regulatory schemes, suggesting that these schemes are not comprehensive. Furthermore, when applying these common law principles, courts are rarely consistent and, at times, are even contradictory. As a result, the robust contractual analysis necessary for achieving an appropriate level of transparency in the regulation of lotteries appears absent.

The analyses offered herein demonstrate that, in reality, the case law only admits of a clear-cut answer in favour of the lottery corporation if courts interpret and supplement the

$1 \quad$ See Ifergan v. Société des Loteries du Québec, Qc. Sup. Ct., No. 500-17-045669-085 [Ifergan] (Statement of Claim [Ifergan Statement of Claim]). 
lottery regulatory scheme with common law contractual principles in a haphazard manner. If, however, courts were more consistent in their interpretation and supplementation of the legislation (particularly with respect to the contractual relationship between the lottery corporation and the individual players), a different result might ensue. The authors therefore suggest that, in such a case, the court has an obligation to clearly articulate the boundaries of the lottery regulatory regime in relation to the common law, while, of course, maintaining fidelity to legislative intent. ${ }^{2}$

Accordingly, in order to expose the boundaries of the common law that are not fully supplanted by the regulatory regime, the authors employ a form of legal realist methodology, that of reverse causality. ${ }^{3}$ That is, the authors begin by first articulating the desired result a finding in favour of the claimant — and then move on to identify the contractual principles that could lead the court toward that outcome. As put by Karl Llewellyn: "although the outcome in the case may be (and commonly is) a function of the rule laid down, the rule laid down may be (and commonly is) a function of the outcome of the case - partly sought for, shaped and phrased for the purpose of justifying the result desired." ${ }^{4}$

It is also important to point out to the reader that the claimant's case originates out of Quebec, a civil law jurisdiction that utilizes the Civil Code of Québec. ${ }^{5}$ The authors, however, have chosen to look at the claimant's dispute through a common law lens in an attempt to bring together different "thought-worlds" using the fantastic example of the claimant. The objective here is to stimulate greater disagreement which, as pointed out by Constance Bagley, is key to reducing "group-think," and can "enhance problem solving by widening scanning activities" and increase access to "historical perspectives" and "multiple function areas." ${ }^{\prime 6}$ Thus, in this article the authors have chosen to explore the claimant's dispute through the lens of the common law in order to expand the scope of the potentially applicable law, provoke greater disagreement, and enhance problem solving with respect to the regulation of lottery corporations, their game rules, and the role that these corporations play in society. It should be noted, however, that the key rules and regulations concerning

2 The object of this article is to identify some of the contractual arguments available to the lottery player in order to encourage the courts to clearly articulate the true nature and scope of the contractual relationship, and to expressly identify the parameters of the regulatory regime. The true essence of this lottery player's dilemma, therefore, ultimately boils down to one of statutory interpretation. As put by Ruth E. Sullivan,

[t]he problem as I see it is not methodological but rhetorical. Faced with a problem in interpretation, a court must not only draw on its skill and integrity to produce appropriate outcomes; it must also offer coherent and acceptable explanations of how its outcome was reached and these explanations must be grounded in a coherent and acceptable theory of the judicial mandate in interpreting legislation.

"Statutory Interpretation in the Supreme Court of Canada," online: University of Ottawa $<$ http://aix1.uottawa.ca/ resulliv/legdr/siinscc.html> [emphasis added].

For further discussion on strategies of reverse causality, see Jean-Claude Woog, La Stratégie du Créancier (Paris: Dalloz-Sirey, 1997). A similar reversal principle is utilized in the context of statutory interpretation, commonly referred to as "consequential analysis": see Ruth Sullivan, Sullivan on the Construction of Statutes, 5th ed. (Markham, Ont.: LexisNexis, 2008) at 299-323. The basics of the two concepts are the same. The person doing the analysis (in legal strategy, a lawyer or a legal academic; in litigation, the court) assesses the competing claims to correctness not by examining the correctness of the legal principles in the abstract, but by trying to foresee the probable consequences that will ensue from the possible alternatives and choosing the alternative that is most likely to produce the most desirable results. K.N. Llewellyn, The Bramble Bush: On Our Law and its Study (New York: Oceana, 1951) at 39. S.Q. 1991 , c. 64.

"Foreword" in Antoine Masson \& Mary J. Shariff, eds., Legal Strategies: How Corporations Use Law to Improve Performance (Heidelberg: Springer, 2010) at vi. 
winning tickets that are relevant to the discussion herein are similar across Canadian provinces, including Quebec. The authors would like to encourage others to conduct similar examinations in the reverse direction, that is, to analyze the common law contractual dilemma from the perspective of the civil law. It is the authors' opinion that these types of unique perspectives are necessary for learning and understanding complexity in the law, and thus, in turn, are critical to the ongoing development of the law of contracts, particularly in light of globalization.

Furthermore, in this article the authors restrict themselves largely (though not exclusively) to contractual remedies because of the apparent consensus in the courts that the relationship between a lottery player and a lottery corporation is contractual. ${ }^{7}$ This is not to say that other arguments, including those based in tort, should not also be canvassed given that there is an actual winner in this circumstance who arguably should receive the full prize amount. ${ }^{8}$ That being said, the authors believe that arguments based on contract are both sufficiently important and nuanced to warrant their own exploration. Therefore, contractual arguments are the focus of this discussion.

Part II of this discussion sets out the facts of the Ifergan case and summarizes the pleadings of Loto-Québec. Part III explores and summarizes current Canadian lottery cases, with particular focus on the courts' interpretation of the rules and regulations relevant to the the claimant's fact scenario. The review of the case law introduces some of the policy concerns that make recourse to breach of contract arguments undesirable in lottery ticket dispute cases. Part III also considers the inconsistent and contradictory approach that the courts have taken when applying relevant common law contractual principles to supplement the regulations. It concludes by confirming that Loto-Québec's pleadings are consistent with, and supported by, the case law reviewed. Part IV proceeds with a consideration of the potential common law contractual arguments that, arguably, are not supplanted by the rules and regulations, and could support a finding in favour of a lottery ticket purchaser in these particular circumstances. Part IV then returns to address the issue of the undesirability of breach of contract claims in light of the lottery scheme's need for certainty in ticketing. Part $\mathrm{V}$ considers the potential application of current electronic commerce legislation to the claimant's scenario, and discusses additional policy arguments in favour of the lottery player. Finally, Part VI concludes by offering some preliminary comments as to which arguments might be most persuasive for the court, should it wish to find in favour of the lottery player.

The goal of this discussion is not to assert that one solution to the dispute is to be preferred over another. Rather, the overall objective of this article is to demonstrate that when a court supplements regulations with the common law, but fails to provide a coherent explanation of the role and scope of the common law, not only is the statutory interpretation exercise questionable, but the development of the common law and the evolution of legislation are

7

See e.g. McKay v. Flin Flon Junior Bomber Hockey Club (1999), 135 Man. R. (2d) 183 (Q.B.) [McKay]; Group Against Smokers' Pollution v. Manitoba (Lotteries Licensing Board) (1980), 5 Man. R. (2d) 1 (C.A.) $[G A S P]$.

8 An examination of the arguments that might be made on the basis of tort law generally and, in particular, the law of negligence, is outside of the scope of this article. However, it should be pointed out that the authors also believe that there is room to make such arguments based, inter alia, on the apparent operation of the computer system, which did not allow for a reasonable game break for data entry and processing, and the mischief that has arisen therefrom. 
also impeded. Understanding and articulating the functional boundaries of the law, as established by both the relevant regulatory regime and the common law, is critical to transparency and fairness in its application. One way to explore this boundary is to encourage vigorous legal analysis through explicit reverse causality methodology.

\section{THE FACTS ${ }^{9}$}

On Friday, 23 May 2008, at approximately 8:58 p.m., the claimant stopped at a convenience store. ${ }^{10}$ He asked the clerk whether there was sufficient time to purchase tickets for the Super 7 draw to be held later that night. ${ }^{11}$ The clerk, who was also the sole shareholder of the corporation operating the store, consulted the clock on the lottery terminal machine and indicated to the claimant that there was one minute left ${ }^{12}$ before the deadline. ${ }^{13}$ The deadline was understood to be 9:00 p.m. that Friday night. ${ }^{14}$

The claimant requested two "Quick Pick" tickets with five series of numbers on each. ${ }^{15}$ According to the claimant's account, the clerk completed the data entry actions necessary to issue the tickets when the lottery terminal clock still read 8:59 p.m. ${ }^{16}$ The clerk told the claimant that they "got them in on time," which indicated to the claimant that both tickets purchased were for that evening's draw. ${ }^{17}$

However, when the tickets printed, the clerk noticed that the two sets of tickets indicated two different draw dates. The clerk commented that this was "strange"18 because the lottery terminal clock read 8:59 p.m. when the tickets were both requested ${ }^{19}$ and entered. ${ }^{20}$ The first ticket printed bore the Friday, 23 May 2008 draw date, but the second ticket printed was dated for the next draw, scheduled for Friday, 30 May 2008. ${ }^{21}$ The clerk asked the claimant if he still wanted the ticket, to which the claimant (perhaps not surprising to most players of

These facts are drawn from both the claimant's account, and the lottery corporation's (the respondent) defence (as either ignoring or denying the claims of the claimant). They have not as yet been found by a court as an accurate account of the interactions between the parties.

Ifergan Statement of Claim, supra note 1 at para. 1. See also Ifergan, supra note 1 (Statement of Defence) [Loto-Québec Statement of Defence]. All court documents cited are on file with the authors. The respondent has no comment on this issue: Loto-Québec Statement of Defence at para. 1. Statement of Defence, ibid. Ifergan Statement of Claim, ibid. at para. 3. The respondent has no comment on this issue, other than to point out that the claimant waited until the very last minute to make his purchase: Loto-Québec Statement of Defence, ibid. at para. 2. Québec Statement of Defence, ibid. at para. 38. Ifergan Statement of Claim, ibid. at para. 44. The respondent relies on the wording of the ticket: LotoQuébec Statement of Defence, ibid. at para. 39.

Ifergan Statement of Claim, ibid. at para. 4. The respondent denies that there was a purchase of tickets: Loto-Québec Statement of Defence, ibid. at para. 3. Ifergan Statement of Claim, ibid. at paras. 5-8, 29-31.

Ifergan, supra note 1 (Examination for Discovery/Deposition of Joel Ifergan (8 January 2009) at paras. 87-88 [Ifergan Discovery]). See also Ifergan Statement of Claim, ibid. at paras. 9, 29-31. The respondent denies that there was a purchase of tickets: Loto-Québec Statement of Defence, supra note 10 at para. 3.

Ifergan Statement of Claim, ibid. at paras. 10-12. The respondent views this as an admission on the part of the claimant: Loto-Québec Statement of Defence, ibid. at para. 6.

Ifergan Discovery, supra note 17 at para. 89.

Ifergan Statement of Claim, supra note 1 at para. 12. The respondent denies this: Loto-Québec Statement of Defence, supra note 10 at para. 7.

Ifergan Statement of Claim, ibid. at para. 14. The respondent acknowledges the content of the ticket: Loto-Québec Statement of Defence, ibid. at para. 9. 
games of chance) replied, "I purchased it, it’s mine.”22 The claimant then paid for all the tickets. $^{23}$

On Saturday, 24 May 2008, the lottery corporation, Loto-Québec, announced that there was a single winner for the Friday, 23 May 2008 jackpot of \$27 million. ${ }^{24}$ The claimant’s second ticket held the winning combination of numbers but, as already noted, the second ticket was dated for the draw scheduled for Friday, 30 May 2008, not the draw held on Friday, 23 May 2008. ${ }^{25}$

The lottery corporation, Loto-Québec, found that the first ticket had registered with its computer three seconds prior to the deadline, but that the second ticket registered seven seconds after the deadline. ${ }^{26}$ The corporation claimed that its central computer system does not accept two requests simultaneously; rather, there can be a delay of up to ten seconds on each ticket request. ${ }^{27}$ Therefore, in the corporation's opinion, the computer system was to blame. ${ }^{28}$ The claimant further claimed that the lottery advertising at the retailer's premises indicated that the ticket would be valid for that night's draw if the numbers were purchased by 9:00 p.m., not purchased and processed by the respondent's central computer by 9:00 p.m. ${ }^{29}$ Because there was another winner who held the same numbers for the 23 May 2008 draw, the claimant's claim is for $\$ 13.5$ million, that is, one half of the jackpot prize of \$27 million. ${ }^{30}$

The arguments of Loto-Québec can be summarized as follows: ${ }^{31}$

(1) The game is governed by the lottery rules and regulations, of which the claimant is well aware given that he has been playing the lottery for 35 years;

(2) The lottery corporation has an obligation to pay only when a valid winning ticket is produced;

(3) The claimant did not produce a winning ticket;

$22 \quad$ Ifergan Discovery, supra note 17 at para. 91.

23 Ifergan Statement of Claim, supra note 1 at para. 13. To the extent that there is an admission in this paragraph, the respondent acknowledges such admissions, but otherwise denies this: Loto-Québec Statement of Defence, supra note 10 at para. 8. The respondent also claims that: (1) the claimant had full knowledge of the fact that the ticket was for the draw scheduled for 30 May 2008, and (2) the claimant purchased the ticket after 9:00 p.m.

24 Ifergan Statement of Claim, ibid. at para. 16. The respondent ignores this: Loto-Québec Statement of Defence, ibid. at para. 11.

25 Ifergan Statement of Claim, ibid. at para. 15. The respondent acknowledges the content of the ticket: Loto-Québec Statement of Defence, ibid. at para. 10.

26 Ifergan Statement of Claim, ibid. at para. 25. The respondent simply acknowledges the content of the exhibit designed to confirm the allegation: Loto-Québec Statement of Defence, ibid. at para. 20.

27 Ifergan Statement of Claim, ibid. at para. 38. The respondent denies this: Loto-Québec Statement of Defence, ibid. at para. 33.

28 Ifergan Statement of Claim, ibid.

29 Ibid. at para. 45. The respondent denies this and adds that the date on the ticket is determinative: LotoQuébec Statement of Defence, supra note 10 at para. 40.

30 Ifergan Statement of Claim, ibid. at para. 42. The respondent denies this: Loto-Québec Statement of Defence, ibid. at para. 37.

31 Loto-Québec Statement of Defence, ibid. at paras. 51-66. See also By-law respecting forecast contests and numbers games, R.R.Q. 1981, c. S-13.1, r. 1, ss. 9 (Refusal of Wager), 16 (Winning Lottery Ticket), 22 (Liability of the Company). 
(4) The claimant requested a last-minute ticket, which was accepted and paid for after 9:00 p.m.;

(5) Pursuant to the applicable regulations, the lottery corporation can, at its discretion, refuse to issue tickets at any time; and

(6) The lottery corporation has no liability to the claimant, given that his claim is not founded on a valid winning ticket.

\section{LOTTERY CASE LAW}

\section{A. SUMMARY OF LOTTERY CASES}

For this section, we have reviewed all Canadian case law relating to disputes over lottery winnings. ${ }^{32}$ After a recitation of the relevant facts and law, the legal principles and policy that we identify as being important and relevant to this particular discussion are summarized in Part III.B, below.

In $M c K a y,{ }^{33}$ the rules on the back of the ticket indicated that the first name drawn was to receive first prize, the second name drawn was to receive second prize, and so forth. The purchaser's ticket was drawn third and was awarded the third place prize by the hockey club. A radio announcement, however, had mistakenly announced that the ticket purchaser had won the first place prize instead of the third place prize.

The purchaser sued, arguing that, based on the radio announcement, she had a right to the first place prize. The Court found in favour of the hockey club, stating, inter alia:

\footnotetext{
The ticket is an offering to the public and the people who purchase a ticket accept the offering. The contract, which is created between the defendant and anyone who purchases a ticket, is as set out in the ticket. The defendant is unable to unilaterally change the terms of the contract unless there is agreement that it could do so. There is nothing on the ticket which would indicate that a change could be made unilaterally by the defendant. The defendant never consulted with any of the ticket holders prior to the draw to get their permission. $^{34}$
}

In GASP ${ }^{35}$ the Group Against Smokers’ Pollution (GASP), a charitable organization, held a lottery contest under licence. The holder of the winning ticket did not come forward to claim the prize, a car. The issue was whether GASP could retain the car for charitable activities, either holding it in trust (which would fail because of the unascertained beneficiary) or on the basis of the relationship between GASP and the purchaser as being one governed by contract. The Court held that it was preferable to decide the matter on the basis of contractual principles, as opposed to trust principles, but did not hold this determination

All Canadian cases dealing with individuals and various lottery corporations across Canada as of August 2009 are included here, with the exception of Gallant v. Atlantic Lottery Corp., [1987] N.B.J. No. 229 (Q.B.) (QL) (concerning termination of contract between the lottery corporation and an agent retailer). Supra note 7.

Ibid. at para. 4 [emphasis added].

Supra note 7. 
to be essential to its findings. In either case, the Court held in favour of GASP. The vehicle was to remain in possession of GASP until delivery to the winner. If the winning ticket was produced, GASP would be contractually liable to deliver the vehicle in accordance with the rules of the lottery. In the absence of the production of the ticket however, GASP, as the owner, would be entitled to use the vehicle or proceeds from its sale for its charitable purposes. This was held to be in accordance with the offer made by GASP when it sold the tickets.

In Budai v. Ontario Lottery Corp., ${ }^{36}$ a ticket holder spent a portion of his anticipated winnings (US\$480) after a computer printout had identified that he had won $\$ 835.40$. When he went to collect his winnings, however, the lotteries corporation advised him that there had been a computer error and that, according to the rules and regulations, he was only entitled to a $\$ 5$ prize. The Court agreed that, according to the rules and regulations, the ticket holder was only entitled to $\$ 5$, and the erroneous computer printout did not change this fact. However, because the claimant had reasonably relied on the corporation's negligent misrepresentation, the Court held that he was entitled to US\$480, the amount he had spent in reliance on the misrepresentation.

In McCorkell v. Ontario Lottery Corp., ${ }^{37}$ the plaintiff, a long-time player of Lotto 6/49, had selected three sets of numbers on a selection slip, but only two of the three sets selected were reflected on the printed ticket. The clerk, incorrectly assuming that a crease in the slip had caused the problem, voided the third selection and copied those numbers onto a fourth board. The clerk fed the slip into the terminal and provided the plaintiff with two tickets, stating: "You're okay now." ${ }^{38}$ The plaintiff did not check the tickets, which would have revealed that it was the first set of numbers that had been omitted, not the third set. Consequently, neither ticket contained the first set of numbers. When the relevant draw was held, five out of the six numbers matched the plaintiff's unentered selection, which would have entitled the plaintiff to a half share in the second place prize of $\$ 432,818$. The plaintiff argued that in consideration of his $\$ 3$ payment, the corporation agreed to sell, and he agreed to buy, a ticket bearing three number combinations chosen by him on the selection slip. He did not receive one of the selections he had bargained for. By failing to provide him with the three chances paid for, the corporation, as principal for the acts and representations of its authorized sales agent, was guilty of breach of contract and liable in the amount equal to the amount that he would have won had the contract been properly performed.

The Court held that if a player fails, through negligence or otherwise, to make certain that the numbers on the ticket correspond to the ones on their selection slip, they cannot later complain that the ticket did not adequately reflect their selection. The selection slip set out the terms and conditions/rules of the game, including that it was the player's responsibility to make sure that the numbers on the ticket were the ones they had chosen. Players were also advised that the lottery was governed by certain legislation and regulations. According to the Court, these regulations defined a winning ticket as "a ticket bearing a number or numbers corresponding, in such manner as the Corporation shall determine, to a winning number or

(1983), 142 D.L.R. (3d) 271 (Ont. H.C.J.) [Budai]. (1992), 8 O.R. (3d) 1 (Ct. J. (Gen. Div.)) [McCorkell]. Ibid. at 4. 
numbers drawn as provided in section 6 or a ticket bearing such legend as the Corporation shall determine ... and s. 8(a) makes it a condition for entitlement to collect any prize that the claimant 'satisfy the Corporation that he is a winner.",39

The Court held that the lotteries corporation had not acted arbitrarily or unreasonably in deciding that the plaintiff was not a winner. The plaintiff was unable to satisfy the condition precedent that he was entitled to the prize. The Court provided the following additional reflection:

\begin{abstract}
It is to be borne in mind that we are concerned here with the operation of a lottery which, by definition, is the distribution of prizes by chance where participants make a payment or consideration in return for obtaining the chance of a prize. In the case of this lottery, the chances of winning a major prize are, we are told, in the neighbourhood of a million to one, and are no more or less on any one combination of numbers than on any other. Accordingly, the chances of a player who is unknowingly (because he or she did not check) issued a ticket which, say, because of some malfunction in the terminal or computer glitch, incorrectly recorded the numbers chosen on the selection slip are not diminished by the error. Indeed, should the incorrect ticket turn out to be a winning ticket, as the holder of that ticket, the player would unquestionably be a winner even though the numbers on the ticket were not, in fact, the ones he or she had chosen. If, on the other hand, the numbers chosen on the selection slip turned out to be winning numbers, on the plaintiff's argument, the player, having clearly sustained a loss as a consequence of not being given the ticket for which he or she had bargained, would be entitled to damages for breach of contract....This result is manifestly untenable. $^{40}$
\end{abstract}

In Sullivan v. Atlantic Lottery Corp., ${ }^{41}$ a lottery marketing brochure erroneously indicated that correctly selecting four out of six numbers would entitle the winner to a share in the third prize pool, as opposed to the fourth prize pool. A correction was mailed out but not received by the plaintiff. The plaintiff's ticket matched four numbers, but when she went to confirm her prize from a convenience store lottery terminal she was given two printouts: one indicating that she was entitled to $\$ 1,272.60$ and the other indicating that she was entitled to $\$ 46.70$. When the plaintiff raised the issue with the lotteries corporation, it advised her of the error in the brochure and indicated that she was the winner of the lesser prize. The plaintiff sued.

The Court held that, even if the plaintiff had relied upon the original brochure, because there were 5,535 people with four correct numbers, she would only have been entitled to $\$ 46.70$ in any event. Additionally, although the lottery carelessly and falsely led the plaintiff to believe that she would receive a share in the larger amount - a negligent misrepresentation in breach of their duty of care to their customers - there was no evidence that disappointment in not receiving just under $\$ 1,300.00$ would cause mental shock to an ordinary strong nerved person. Natural disappointment in this case is not mental shock. The Court held that 
[i]f the amount were much larger, it might be said that the foreseeable result of the negligence was mental shock on the part of Mrs. Sullivan. Although I am satisfied that Mrs. Sullivan was unhappy, disappointed or annoyed, there is no evidence to suggest that her disappointment in not receiving \$1,272.60 would cause “an ordinary strong-nerved person” ... a mental shock comparable to, for example, witnessing a violent death ... or perhaps being negligently advised of having won a million dollar lottery. ${ }^{42}$

In Reynen v. British Columbia Lottery Corp. ${ }^{43}$ the plaintiff (along with a later deceased partner) used historical lottery data to develop a system for narrowing odds. When the lottery corporation became aware that the plaintiff intended to purchase large blocks of tickets, the corporation, concerned that the integrity of the game might be threatened, made a decision to disallow retailers from selling massive amounts of tickets to individual purchasers. The plaintiff sued for breach of contract, arguing that, had he been able to purchase the tickets, he would have selected a winning ticket. The plaintiff also sued for breach of statutory duty and negligent misrepresentation based on the corporation's failure to warn retailers of the possibility that large purchases could be disallowed. The Court dismissed all actions. With respect to the breach of contract argument, the rules and regulations of the enabling Act gave the lottery corporation the discretion to refuse a sale - the corporation had the right to revoke an offer prior to acceptance, which could not occur until the tickets were actually purchased.

Furthermore, the Court held that, on these facts, the substantive elements required to demonstrate the existence of a contract, such as offer and acceptance, mutuality, and the existence of agreed upon terms were absent. "At best,” the circumstances represented an invitation to treat by the corporation to the general public, which included a right of reservation to refuse to sell tickets. ${ }^{44}$ No contract, express or implied, was formed between the parties.

With respect to the statutory duty of care, the Court held that the corporation's decision to disallow the sale was a bona fide policy decision and, therefore, was not subject to a duty of care. The Court also held that the corporation was not negligent in failing to warn retailers that large purchases might be disallowed, although it may have been inaccurate and misleading. The sales were disallowed pursuant to the rules that were posted at all retailers and referred to in all of the promotional material, selection slips, issued tickets, and so on. ${ }^{45}$ Even if there was negligence, there was no reliance because the plaintiff was aware that the rules gave the corporation discretion to refuse sales. Additionally, if there was reliance, the Court held that it was not reasonable. Furthermore, if reliance could be said to have been reasonable, the only costs incurred would be those specifically incurred by the plaintiff in preparation for the draw, which did not include costs incurred to make the overall system operational. $^{46}$

Ibid. at para. 18 [citations omitted, emphasis added]. [1997] 10 W.W.R. 706 (B.C.S.C.) [Reynen].

Ibid. at para. 48.

Ibid. at para. 86.

Ibid. at para. 92. 
In Hardie v. British Columbia Lottery Corp., ${ }^{47}$ the plaintiff held one of two winning tickets sold for a Lotto 6/49 Bonus \$1 million pool draw. When the second winner had not come forward by the time the limitation period for claiming the prize had passed, the plaintiff brought an action to claim the other half of the prize. The Court held that, according to the rules and regulations, winning tickets are entitled to share prizes based on the number of winning selections or tickets that exist, not on the presentation of winning tickets to the lottery corporation. Accordingly, the plaintiff's claim was dismissed.

In Budney v. Western Canada Lottery Corp. ${ }^{48}$ the plaintiffs purchased a scratch ticket that revealed one PT Cruiser symbol and claimed to have won that prize. The lottery corporation declined to award the prize on the basis that they had not uncovered three symbols in accordance with the rules on the back of the ticket, which stated, inter alia:

If you find three (3) identical symbols (other than 3 identical dollar amounts), you win the prize in the corresponding PRIZE box. If the PRIZE is a [PT SYMBOL], you win a 2001 PT Cruiser $^{\mathrm{TM}}$, selected by the WCLC, or the sum of $\$ 30,000{ }^{49}$

The plaintiffs argued that a winning ticket only required that one PT Cruiser symbol be displayed in the prize box, as opposed to three identical symbols. In dismissing their claim, the Court held that anyone familiar with the English language would be aware, upon reading the rules, that three identical symbols would be required for a win. Contracts are to be interpreted based on the intention of the parties, which is normally dependent on the ordinary usage of language. When documents are clear and unambiguous, the four corners of the contract are to be adhered to and it is unnecessary to resort to extraneous matters.

In Murphy v. Western Canada Lottery Corp. ${ }^{50}$ the plaintiff attempted to collect a winning prize with a photocopy of the winning ticket after her wallet containing the original ticket had been stolen. The lottery corporation rejected her claim even though no other person had attempted to claim the prize, and the time for doing so had expired by the time of the hearing. The governing rules and regulations did not state that an original ticket had to be produced.

The Court held that the plaintiff and the defendant lottery corporation were in a contractual relationship and that, where there is ambiguity, the contract must be interpreted contra proferentem. The terms of the contract were the governing rules and regulations, and they were ambiguous on this point. The Court further acknowledged that r. 15(a) of the Western Canada Lottery Corporation's Rules and Regulations Respecting Lotteries and Gaming, ${ }^{51}$ which states that a person must satisfy the corporation that they are a winner, gives the lottery corporation a tremendous amount of discretion and that the Court should not lightly interfere with the corporation's decisions. However, the Court should intervene when the corporation acts in an arbitrary, unreasonable, or unfair manner, which was the case here - the corporation was declining to declare a person a "winner," despite the fact that the 
person fit within the definition of a winner as set out in the rules; a "true copy" of the winning ticket fell within the definition of a "winning ticket.” The corporation was in breach of contract and the plaintiff was entitled to the $\$ 100,000$ prize. This decision was affirmed by the Court of Appeal. ${ }^{52}$

Despite its affirmation of the trial judge, the Court of Appeal also held as follows:

Given the unique factual circumstances in this case, we agree with the trial judge that this case should not be considered a precedent which might give rise to the sort of mischief the appellant anticipates. In any event, we note that it is open to the appellant to amend its own Rules and Regulations to clearly and unequivocally clarify its position regarding the necessity to produce an original ticket. ${ }^{53}$

In Karagiannis v. Western Canada Lottery Corp., ${ }^{54}$ the plaintiff tore up his combination play lottery ticket for a televised football league match before the end of the game. When the plaintiff's ticket turned out to be a winning ticket entitling him to a prize payout of $\$ 1,319$, the plaintiff taped the ticket back together and submitted his claim to the lottery corporation. The corporation declined to award the prize on the basis that the ticket was "voided," because it was mutilated or incomplete, in contravention of the gaming regulations. The plaintiff brought an action for breach of contract.

The Court held that the contract was consummated, and the parties bound, when the ticket was purchased, and was governed by the terms as contained in the lottery rules and regulations incorporated by reference on the back of the issued ticket. The bar code identified it as the winning ticket, and there was no evidence that another third party was entitled to a payout. The purpose of the gaming regulation concerning the non-alteration of tickets was "to ensure and verify accuracy of the winning ticket and prevent fraudulent or improper payout." 55 The regulation was not to serve as a penalty disentitling an otherwise lawful claimant.

In Thierman v. Western Canada Lottery Corp., ${ }^{56}$ the plaintiff sent in a renewal form for his Lotto 6/49 subscription three weeks before it was due to expire on 22 January 1992. The form stated as follows:

NOTE: Since the Corporation cannot ensure the first draw date, please allow approximately four weeks for processing. A Subscription shall be deemed to have been received by the Corporation on the date of the first of the next of the consecutive draws following the date on which the ticket numbers contained in the Subscription are recorded in the Computer System. ${ }^{57}$

Additionally, the rules set out that the liability of the corporation, whether in negligence or otherwise, was limited to the amount wagered. A notice accompanying the renewal notice further advised of a 17-day cut-off prior to the draw. There was evidence that this was

2004 ABCA 137, 348 A.R. 349 [Murphy (C.A.)].

Ibid. at para. 10 [emphasis added].

2003 SKPC 123, 240 Sask. R. 289 [Karagiannis].

Ibid. at para. 31 .

(1995), 133 Sask. R. 303 (Q.B.) [Thierman].

Ibid. at para. 3 . 
required to "enable subscribers' cheques to clear their accounts and to enable a subscriber to check the numbers in the new certificate."58

A delay in processing caused the renewal subscription to commence on 29 February 1992, one month after the expiry date. On 19 February 1992, the plaintiff's subscription numbers were drawn on a $\$ 2$ million jackpot. The lottery refused to allow the plaintiff a share in the jackpot, and the plaintiff sued for breach of contract. The plaintiff relied on the "fine print" cases, where consumers are not expected to read or understand the contract, and the "courier cases," which look at the reasonable expectations of the parties, ${ }^{59}$ to determine if the failure to perform the contract in a timely fashion constitutes a fundamental breach. The Court dismissed the action, stating:

Here, WCLC made a public offer that it would award prizes on the basis of the terms and conditions contained in the various documents which have been entered in evidence. In particular, were the conditions contained on the back of the plaintiff's renewal application form, which he had read and understood.

These documents constitute the "offer" and to act upon it, a contestant must bring himself within the terms of the "offer". These terms required that his application be entered in the computer and restricted the defendant's liability to the amount wagered. In my opinion, the plaintiff's claim cannot succeed. His claim is, therefore, dismissed with costs. ${ }^{60}$

\section{B. SuMMARY OF RelEVANT PRINCIPLES}

The principles that are clearly articulated by the case law can be summarized as follows:

Ibid. at para. 4 .

The law of contracts often seeks to achieve a balance between doctrinal concerns, on the one hand, while still giving effect to the reasonable expectation of the parties, on the other. For example, the authors see a parallel between the position advocated here and the law of tenders. In Ontario (Water Resources Commission) v. Ron Engineering Ltd., [1981] 1 S.C.R. 111, Estey J. developed the well-known Contract $\mathrm{A} /$ Contract $\mathrm{B}$ framework in order to protect the reasonable expectations and interests of tenderers, who, among other things, invest time, resources, and money in preparing a bid. Applied to the lottery context, Contract A would be a contract with each ticket holder, and Contract B would be the contract to pay out the prize to the winning ticket. While the policy arguments for a Contract A/Contract B framework are different for tendering cases, policy arguments still exist in a lotteries setting. As discussed in Part V of this paper, the government takes advantage of and profits from players. The rules of the game must be known and equitably applied to all players. This concept is not foreign to advertising or lottery cases. Indeed, the reasonable expectations of the parties are explicitly part of the resolution in Carlill $v$. Carbolic Smoke Ball Company (1892), [1893] 1 Q.B. 256 (C.A.) [Carbolic Smoke Ball], where the Court describes the acceptance of an advertised proposition as creating a contract with all those who performed as requested in the advertisement. Furthermore, the need to respect the reasonable expectations of the parties is described in McKay, supra note 7 at para. 4, where the Court said that there is a contract with all ticket holders and it is not open to the corporation to change the rules of the game unless all players are contacted and informed. Together, then, we see that the courts have the power to use traditional contractual principles to achieve what the parties themselves set out to accomplish. Where the clear and reasonable expectations of the parties would be defeated by the application of these principles, however, the courts have also reserved the right to develop different mechanisms (like the Contract A/Contract B analysis or the identification of advertisements as an offer) to protect (and give effect to) the reasonable expectations of the parties. 
- The purchase ${ }^{61}$ of a ticket constitutes acceptance of the lottery offer on the terms indicated on the ticket; ${ }^{62}$

- $\quad$ Lottery drawings are governed by statutory rules and regulations; ;3 $^{63}$

- Upon production of a winning ticket, the lottery corporation is contractually liable to deliver the prize to the holder in accordance with the rules of the lottery; ${ }^{64}$

- A winning combination and prize amount are determined by statutory rules and regulations. Therefore, for example, a third party mistake, a computer printout, or a brochure do not alter the terms of the contract or necessarily reflect the prize won. ${ }^{65}$ However, where there is ambiguity in the rules and regulations, the contract must be interpreted contra proferentem; ${ }^{66}$

- The rules applicable to a given lottery may indicate that the claimant must satisfy the lottery corporation that they are a winner in accordance with the regulations. ${ }^{67}$ This is a condition precedent to collecting prize money that gives the lottery corporation a tremendous amount of discretion. ${ }^{68}$ A court should not interfere lightly with the lottery corporation's decisions. ${ }^{69}$ However, a court should intervene when the lottery corporation acts in an arbitrary, unreasonable, or unfair manner; ${ }^{70}$

- It is the lottery player's responsibility to make sure that the ticket received is the one that they have chosen; ${ }^{.71}$

- $\quad$ The comments of a lottery agent do not relieve the claimant's responsibility. "[G]iven the nature of this kind of wagering transaction, and the obvious potential for abuse if it were otherwise, players are not relieved of the responsibility by the words or conduct of Lotto 6/49 sales agents or operators"; ${ }^{72}$

The term "purchase" is used here, notwithstanding that the definition of "purchase" is not articulated by the case law reviewed.

McKay, supra note 7 at para. 4. See also Reynen, supra note 43 at para. 47; Karagiannis, supra note 54 at para. 27.

See generally Budai, supra note 36; McCorkell, supra note 37; Reynen, ibid.; Karagiannis, ibid.; Hardie, supra note 47; Budney, supra note 48.

GASP, supra note 7 at para. 30.

See McKay, supra note 7; Budai, supra note 36. See also Sullivan, supra note 41.

See Murphy (Q.B.), supra note 50 at para. 11. There are cases that suggest that the rule of contra proferentem is inapplicable to a statutory contract. See, for example, the judgment of Spence J. (otherwise dissenting, but speaking for the Court on this point) in Madill v. Chu, [1977] 2 S.C.R. 400. The discussion there was with respect to a mandatory addition to all Ontario insurance contracts made between two other parties. This rule makes sense in this context. Why would a statutorily required contractual provision be interpreted in favour of one party (and, consequently, against the other party) when neither has any control over the provision or its wording? However, in the case of lotteries, the government (or, in this case, a Crown corporation) is in fact a party to this contract. Therefore, it has more control over the statutory (or regulatory) provisions than a private sector insurer. While there are similar cases involving public insurers, the statute and regulations in the case of lotteries prescribe neither the timing of the deadline nor how that deadline is supposed to be applied. Therefore, in the view of the authors, the cases that deny the application of the rule of contra proferentem are not applicable on these facts.

Ibid. at para. 25.

See ibid. See also McCorkell, supra note 37 at 6-7.

McCorkell, ibid. at 10.

Ibid. at 9 . 
- The acts of lottery agents "cannot ... reasonably be relied upon to affect the express instructions to participants or override the basic structure of the game”, ;3

- Limitation of liability clauses can serve to limit the available remedy in any event; ${ }^{74}$

- A lottery corporation can be held liable for negligent misrepresentation when there is detrimental and reasonable reliance on a misrepresentation as to the prize. ${ }^{75}$ It may be possible to demonstrate mental shock for negligent misrepresentation if the misrepresented amount was large. ${ }^{76}$

What remains unclear from the case law is whether lottery advertisements for the sale of lottery tickets are offers ${ }^{77}$ or invitations to treat. ${ }^{78}$ While the purchase of a ticket has been held to be an acceptance of an offer, ${ }^{79}$ the courts have also described lottery sales to the public as invitations to treat, sometimes even in the same breath. ${ }^{80}$ The courts' failure to properly define the elements of the transaction is significant to the arguments to be made on both sides and is discussed in further detail below.

Additionally, based on McCorkell, where a player alleges that they did not receive the ticket requested the courts may be disinclined to permit breach of contract arguments when the player has been issued a ticket in substitution that provides them with the equivalent chance of winning. ${ }^{81}$ The concept here is that the lottery corporation would not be able to refuse payment if the substituted ticket turned out to be a winning ticket. Therefore, according to the Court, it would be inappropriate to give the player a second option for obtaining compensation based on a breach of contract when their chance at winning with the substituted ticket was the same — the player simply cannot have it both ways.

Aside from the factual hoop jumping that would have to occur in order to get such a hypothetical to actually play out, the consequentialist symmetry that the Court appears to be imposing hinges on the notion of chance. More specifically, if the substituted chance is equivalent to the chance for which the player contracted, the player has suffered no compensable loss. Whether this was indeed the case on the Ifergan facts is discussed in Part IV, below. Furthermore, in McCorkell the Court appears to be dismissing the breach of contract claim on the basis that there has been no breach because of the substitution. The Court, however, neither expressly articulates this lack of breach nor does it identify the elements, scope, or nature of the contract between the parties. These items are all relevant in assessing the equivalency of the substitution provided as well as the loss of chance. We resume this discussion in Part IV.A.5.d, below.

Ibid. at 9-10.

Thierman, supra note 56 at paras. 3, 23, 26.

See generally Budai, supra note 36. See also generally Sullivan, supra note 41.

Sullivan, ibid. at paras. 23-25.

See Thierman, supra note 56 at para. 25.

An invitation to treat is an invitation to the general public or a specific class of persons to negotiate or make an offer. Not being an offer, an invitation to treat cannot create binding contractual obligations. Only an offer made pursuant to the invitation and a corresponding acceptance by the inviting party can create a binding legal obligation.

See McKay, supra note 7 at para. 4. See also Reynen, supra note 43 at para. 47.

See Reynen, ibid. at paras. 47-48.

Supra note 37. 


\section{Arguments in SuPport OF THE LotTery CoRPoration}

Based on the foregoing, it is clear that Loto-Québec's arguments, as noted above, are in keeping with the case law, and that the odds are stacked against a claimant such as Ifergan. The lottery corporation's argument that the claimant does not hold a "winning” ticket is well supported because it is highly unlikely that the claimant will be able to satisfy the condition precedent that he is a winner in accordance with the regulations - his ticket does not bear the correct date or, as carefully put by Loto-Québec in its Statement of Defence, his ticket does not bear the winning numbers for either draw. ${ }^{82}$ Additionally, the claimant was a frequent player; he knew about the rules and knew that the ticket printed was for a different date, yet he paid for it anyway after the 9:00 p.m. deadline, possibly indicating either his acceptance or affirmation of either new terms or a substitution. Furthermore, in accordance with the case law, nothing that the clerk/agent said to the claimant can override the basic structure of the game, and the lottery corporation can exercise its broad discretion to refuse a ticket request. The lottery corporation will suggest that declining to award a prize for these reasons is neither arbitrary nor unfair.

If these arguments are accepted, in order for the claimant to succeed he will have to persuade a court that the mischief caused by the delay between accepting his ticket request and the issuing of the printed tickets creates a dispute that is not fully resolved by the regulatory framework. ${ }^{83}$

Additionally, as discussed immediately above, the lottery corporation might also point out that the claimant was provided with a substitution of an ex ante equivalent chance for the successive draw, and that it would be untenable if he was now permitted to argue breach of contract. As discussed above, in order for the claimant to overcome this hurdle he will have to distinguish his case and demonstrate that he was not provided with an equivalent chance resulting in a breach of contract.

\section{Arguments in Support of THE LotTery Player}

\section{A. LotTery Corporation As OfFeror, LotTery Player as OfFEREe}

Under traditional principles, the lottery corporation must be construed either as the offeror or the offeree for the purposes of contract formation. Using the legal strategy of reverse causality, arguments for the claimant should consider both possible constructions. In either case, however, the claimant does not want to be bound by the date printed on the ticket, but does want to take advantage of the numbers generated. In the view of the authors there is common law to support this position that has not been expressly ousted by the regulation.

If the lottery corporation is construed as the offeror, then it follows that the acceptance of the offer must come from the claimant. In order to succeed under these circumstances, the claimant must be able to demonstrate that: (1) acceptance of the offer occurred prior to the

$82 \quad$ Supra note 10 at para. 53.

83 It is worth noting that Loto-Québec asserts that the mischief was caused by the claimant by his request for a ticket at the very last minute: ibid. at para. 61 . 
9:00 p.m. draw deadline; and (2) the winning number combination, while relevant to damages, is not relevant to the formation or to a finding of breach of the contract formed. This means that the claimant must demonstrate that a valid contract was formed prior to the issuing of the ticket and prior to payment, and that the lottery corporation was in breach when it did not issue the tickets requested by the claimant.

In order for the above argument to be advanced, certain underlying contractual elements must also be considered by a court. These are:

(1) Whether the lottery corporation is, indeed, the offeror;

(2) Whether the agreement is bilateral (a promise for a promise), as opposed to unilateral (a promise for an act);

(3) Whether or not the moment of acceptance is relevant to the formation of the contract;

(4) Whether the agreement is sufficiently certain; and

(5) Whether the breach involves a loss of chance.

Furthermore, it must also be canvassed throughout whether the regulatory regime impacts these common law arguments, and if so, to what extent. Let us deal with each of these five considerations in turn.

\section{THE LOTTERY CORPORATION AS THE OFFEROR}

Based on the lottery case law reviewed, the courts are unclear as to when or how the lottery contract is formed. Indeed, as noted earlier, the courts will sometimes describe lottery promotional advertising as an "invitation to treat," ${ }^{84}$ while, at other times, they will describe lottery advertising as an "offer," with acceptance being either (1) the performance of an act required by the offer (without providing a description of the act required), or (2) the purchase of the ticket. ${ }^{85}$ The idea of the act of purchasing the ticket as the mode of acceptance creates the added complication of deciding whether the acceptance occurs upon the tendering of payment or upon the actual receipt of payment, and also whether the contract is bilateral (a promise for a promise) or unilateral (a promise for an act) in nature. to refuse to sell, with acceptance of the offer only occurring on the purchase of the ticket demonstrating a perception of the lottery advertising as an offer as opposed to an invitation to treat. For example, in GASP, supra note 7 at paras. 27-28, the Court held that in prize-winning contests, where an offer is made in exchange for an act to be performed on the part of the contestant, the performance of the act is an acceptance of the offer and results in a binding contract. The contract comes into existence by the promoter's offer and the contestant's performance of the act required in the offer. In McKay, supra note 7 at para. 4, the Court held that the purchase of a ticket constitutes acceptance of the lottery offer on the terms indicated on the ticket. Post acceptance, the offeror cannot unilaterally alter the terms without obtaining permission of all ticket purchasers prior to the draw. Also, as mentioned earlier, in Reynen, ibid. at para. 48, the lottery circumstances were described as both an offer with the right to revoke it before acceptance and, "[a]t best," an invitation to treat that included the right to refuse to sell tickets. 
In the view of the authors, it is more appropriate to construe the lottery corporation as the offeror based on, inter alia: (1) the contract being one of adhesion, and (2) the advertising of the top jackpot prize as being aimed at affecting consumer behaviour.

\section{a. Adhesion Contract}

The lottery agreement is one of the more quintessential examples of an adhesion contract. A contract of adhesion is one where the terms to be accepted are not subject to negotiation. ${ }^{86}$ Instead, the contract is presented to the offeree on a "take it or leave it" basis.

Indeed, there is no expectation by either party that there will be negotiations in a lottery situation. If the terms were subject to negotiation the fairness of the lottery could be undermined. If one party received more chances in the lottery at a lower (or even the same) cost, this would be unreasonable and unfair to the other lottery players. Accordingly, because negotiations are not contemplated, the advertising of the top jackpot prize is more reasonably understood as an offer that can be accepted if the offeree, the lottery player, can bring themself within the terms of acceptance. Therefore, in the view of the authors, it is quite clear that a lottery is based on contracts of adhesion with lottery players.

Since the offeror is generally understood to control the terms of the offer, ${ }^{87}$ the person who adheres to the contract is the offeree. Here, the lottery corporation sets the terms and the player agrees to adhere to them. ${ }^{88}$ In such a case the lottery corporation is the offeror.

Even if it were possible for the party seeking adhesion to its terms to be the offeree, such a conclusion would (in the view of the authors at least) have to be unmistakable by the terms of the "contract." For the sake of completeness under the reverse causality approach, however, the authors follow the alternative line of reasoning, with the lottery corporation as the offeree and the claimant as the offeror, in Part IV.B, below.

\section{b. Jackpot Advertising is an Offer}

An invitation to treat is a party's non-binding demonstration of a desire to contract. An invitation to treat is not an offer. As John McCamus explains:

\footnotetext{
86 Black's Law Dictionary, 8th ed., s.v. "adhesion contract."
}

87 See John D. McCamus, The Law of Contracts (Toronto: Irwin Law, 2005) at 181-83.

88 For an unusual case where the person who sets the terms of the contracts is nonetheless the offeree, see Manchester Diocesan Council for Education v. Commercial and General Investments Ltd., [1970] 1 W.L.R. 241 (Ch.D.), per Buckley J. (as he then was). However, in that case, the terms of the contract provided, in part, as follows: "The person whose tender is accepted shall be the purchaser and shall be informed of the acceptance of his tender by letter sent to him by post addressed to the address given in his tender and every letter sent shall be deemed to have been received in due course of post” (at 243). Therefore, the provisions of the contract made it clear that there was to be acceptance by the party requesting tenders. This means that the contractual terms themselves contemplated that the person setting the terms would nonetheless be the offeree. This is not the case in the lotteries context. The case law referred to above shows that, despite all the regulatory and contractual elements applicable to lotteries (and written by the lottery corporation), none of this provides a clear indication that the corporation is meant to be the offeree. Therefore, in our view, the more appropriate construction of the contract is that the corporation is the offeror. 
An "invitation to treat" is an invitation to commence bargaining. It is typically understood as an invitation to the other party to make an offer of some kind. The critical distinction between an invitation to treat and an actual offer is drawn on the basis that an offer communicates a willingness to be bound by the next communication of the offeree. ${ }^{89}$

Again, as discussed above, there is no expectation of negotiations in a lottery contract. While there are cases that suggest advertising might only be an invitation to treat, ${ }^{90}$ when advertising is meant to alter or affect consumer behaviour by generating a promise to pay for, as an example, the opportunity to participate in the lottery, the courts have held that these should be considered offers.

For example, in Carbolic Smoke Ball ${ }^{91}$ an advertisement made reference to the fact that the defendant had set aside $£ 1,000$ in a bank account to pay $£ 100$ to any person who became ill after using the product. The plaintiff used the product and then became ill with influenza. The plaintiff sought to claim the reward. The defendant claimed that the advertisement was not an offer, but the Court disagreed, holding that the advertisement constituted a promise, which was accepted by all consumers buying the product. ${ }^{92}$ As such, if the conditions of the promise were fulfilled (namely, the use of the product as directed and becoming ill thereafter), the obligation to pay arose.

Similarly, in the lottery context the advertising of the top jackpot prize is, in the view of the authors, meant to affect player behaviour. One need only look at the correlation between the jackpot size and the last minute rush to purchase tickets at lottery retailers to show evidence of this. ${ }^{93}$ Therefore, not only is the advertisement meant to affect behaviour, there is evidence that it does in fact have this impact. Since this is a contract of adhesion, there is no negotiation. All of the terms of the proposed contract are either ascertainable or known to both parties. Furthermore, as was the case in Carbolic Smoke Ball, the prize is held out and the player accepts the offer. This is consistent with the true nature of the contractual relationship as described in McKay, ${ }^{94}$ which identifies that anyone who purchases a ticket accepts the offer, and a contract is created with all ticket purchasers. It is not until influenza is contracted or, in this case, numbers are drawn, that the offeror becomes contractually obligated to pay out the reward or prize.

See McCamus, supra note 87 at 34 [emphasis added].

See e.g. Pharmaceutical Society of Great Britain v. Boots Cash Chemists, [1953] 1 Q.B. 401 (C.A.) [Boots].

Supra note 59.

This contractual framework of offers to the public is reflected in McKay, supra note 7.

See e.g. "Lotto 6/49 jackpot of \$49M expected to balloon at ticket-buying deadline” CBC News (20 May 2009), online: CBC News <http://www.cbc.ca/canada/british-columbia/story/2009/05/20/mb-lotto-drawjackpot.html>. See also "Lotto 6-49 jackpot could go higher than \$41-million” The Toronto Star (19 March 2010), online: The Toronto Star <http://www.thestar.com/news/ canada/article/782373-lotto-649-jackpot-could-go-higher-than-41-million?bn=1>:

The estimated jackpot only increases with the number of tickets sold and sales were up 40 per cent on Friday. "Historically, \$40 million seems to be that magic number and we do see a huge jump in sales whenever we get to a jackpot that's this big," said Sarah Kiriliuk of the Ontario Lottery and Gaming Corp. Normally sales increase by 23 per cent when the Wednesday jackpot rolls over to Saturday. With it already hitting 40, lottery officials said they don't know how high it may climb before the terminals close at 9 p.m. Saturday. Supra note 7. 
Hence, in our view, the advertisement meets the criteria set out in Carbolic Smoke Ball, and may therefore be considered an offer by the lottery corporation to the world to purchase tickets from authorized lotteries retailers.

Illuminating an offer in this manner, however, creates a potential difficulty for the claimant because it carries with it the possibility that the contract should also be interpreted as being unilateral. If acceptance is construed as the act of purchasing a ticket, unless the claimant can demonstrate that the act requested is the purchase of a ticket based on a willingness/intention to pay, ${ }^{95}$ (discussed further in Part IV.A.3, below) rather than actual payment, the claimant's acceptance might be held to have occurred after the 9:00 p.m. deadline. ${ }^{96}$

Notwithstanding the foregoing, one could still formulate an argument and provide case law to support the position that lottery advertising is a mere invitation to treat. Furthermore, the lottery regulations give the lottery corporation the discretion to refuse to accept wagers or issue tickets, thereby potentially situating the corporation as the offeree. ${ }^{97}$ In the event that the lottery corporation wishes to rely on this particular regulation, which it appears to have done in its pleadings, ${ }^{98}$ it has effectively described itself as an offeree. This characterization of the corporation as the offeree, as discussed above, inherently conflicts with the nature of an adhesion contract. Obviously, the lottery corporation cannot have it both ways. It cannot be the offeree and demand adhesion by the other party as part of contract formation without some explicit indication to this effect. We return to the possibility of treating the lottery corporation as the offeree in Part IV.B, below.

\section{THE AgREEMENT AS BILATERAL}

The courts are often confronted with the task of determining whether a contract between the parties is unilateral (that is, where a promise is made in return for an act) or bilateral (that is, where a promise is made in return for a promise to act in the future) ${ }^{99}$ In the claimant's case, the characterization of the agreement as bilateral arguably makes it easier to more clearly establish acceptance prior to the 9:00 p.m. deadline.

The lotteries case law on this issue is of little assistance because, again, the courts appear to be of two minds. ${ }^{100}$ Admittedly, the Supreme Court of Canada has provided guidance on this point, however, in a case from a different context. In general, where there is ambiguity, the Court favours binding the parties earlier as opposed to later in the process.

See Sanchez-Lopez v. Fedco Food Corp., 211 N.Y.S.2d 953 (New York City Ct. 1961) [Sanchez-Lopez]. See e.g. Petterson v. Pattberg, 161 N.E. 428 (N.Y. Ct. App. 1928) [Petterson]. However, the facts of this case were unusual. In this case, the defendant had attempted to withdraw the offer, but the plaintiff had died subsequent to the action being instituted but prior to trial. At that time, New York law prohibited the introduction of evidence where the now dead party could not dispute it. Therefore, the revocation was inadmissible. See "Notes and Comment” (1928) 14 Cornell L.Q. 66 at 81-82. Thus, the Court was, at least arguably, stretching the bounds of contract law to achieve a just result as between the parties to the litigation.

By-law respecting forecast contests and numbers games, supra note 31, s. 9. Section 9 reads: "The Company may, at its discretion, refuse to accept wagers and to issue tickets for any selection it determines at any time."

Loto-Québec Statement of Defence, supra note 10 at para. 65.

See McCamus, supra note 87 at 32-33.

See supra notes 77-80 and accompanying text regarding offer and invitation to treat. 
In Dawson v. Helicopter Exploration Co. Ltd., ${ }^{101}$ a helicopter company (through the agency of one Mr. Springer) promised to pay a percentage of any realized profits to $\mathrm{Mr}$. Dawson if Dawson went into a remote area with the company by helicopter to assist in the location of certain mineral deposits. The company did not ultimately follow through and later proceeded to develop the site without Dawson. Dawson sued for breach of contract. The Supreme Court was confronted with the company's argument that the offer at issue was designed to create a unilateral contract, a promise in return for an act. Thus, the company's argument was that since the act (flying in to locate the deposits) was not completed by Dawson, there was no contract. The majority of the Court disagreed, however, finding a bilateral contract. Justice Rand, speaking for himself and Fauteux J., as he then was, wrote that the argument of the respondent was as follows:

[T] he offer called for and awaited only the act to be done and would remain revocable at any time until every element of that act had been completed.

The error in this reasoning is that such an offer contemplates acts to be performed by the person only to whom it is made and in respect of which the offeror remains passive, and that is not so here. What Dawson was to do was to proceed to the area with Springer or persons acting for him by means of [Springer's] helicopter and to locate the showings. It was necessarily implied by Springer that he would participate in his own proposal. This involved his promise that he would do so and that the answer to the proposal would be either a refusal or a promise on the part of Dawson to a like participation.

\begin{abstract}
Although in the circumstances, because the terms proposed involve such complementary action on the part of both parties as to put the implication beyond doubt, the precept is not required, this interpretation of the correspondence follows the tendency of courts to treat offers as calling for bilateral rather than unilateral action when the language can be fairly so construed, in order that the transaction shall have such "business efficacy as both parties must have intended that at all events it should have”: Bowen L.J. in The Moorcock (1). In theory ... an offer in the unilateral sense can be revoked up to the last moment before complete performance. At such a consequence many courts have balked; and it is in part that fact that has led to a promissory construction where that can be reasonably given. What is effectuated is the real intention of both parties to close a business bargain on the strength of which they may, thereafter, plan their courses. ${ }^{102}$
\end{abstract}

If the offeror (the lottery corporation) is not passive, that is, if the offeror is to participate in the act of acceptance as set out by the offer, ${ }^{103}$ the contract should not be construed as unilateral because the offeror can defeat acceptance by simply refusing to perform the act requested. Furthermore, in any event, when it is possible to construe a contract as bilateral in nature, rather than unilateral, this is generally preferred. Therefore, in the authors' view, this precept (as Rand J. refers to it) applies with even more force when one of the parties has significant control and discretion over the process, as does the lottery corporation. In order to obtain a chance at winning, a player must bring himself within the terms of the offer, player within its discretion: see By-law respecting forecast contests and numbers games, supra note 31, s. 9. 
which involves obtaining a ticket. The player cannot obtain a ticket without the participation of the lottery corporation. Thus, if the lottery corporation is the offeror, the contract must be bilateral in nature because of the lottery corporation's non-passive and discretionary role in the issuing and printing of tickets. In other words, the lottery corporation, as the offeror, is not passive in the player's acceptance (the act of obtaining a ticket) in exchange for the corporation's promise. As a result of this lack of passivity, in addition to the preferred interpretation towards bilateral agreements, the contract here is more appropriately construed as bilateral. ${ }^{104}$

\section{The Relevance of the Moment of AcCePtance}

In the view of the authors, one of the major hurdles facing the claimant is the characterization of the payment of money to the lottery corporation's agent. If the payment is construed as acceptance, then it is easier to support the lottery corporation's contention that the ticket contracted for does not bear the winning numbers for either draw. ${ }^{105}$

In some situations, however, it has been held that the acceptance of the consideration (in this case, acceptance of the claimant's money) is only performance under the contract, rather than a necessary element of formation. ${ }^{106} \mathrm{~A}$ simple example may assist here. A asks $\mathrm{B}$ to mow A's lawn for \$50. B indicates to A that B is willing to do so. A decides, prior to B doing the work, that $A$ wishes to do the work herself. A, therefore, refuses to tender the money because B is no longer expected to do the work. B wishes to do the work. There is case law from Canada, the United States, and the United Kingdom to suggest that (1) there is a contract, and (2) A has breached its terms. ${ }^{107}$

A complete discussion on the distinction between unilateral and bilateral contracts is outside the scope of this paper. However, if the lottery corporation asserted (as the offeror) that the agreement at issue was indeed a unilateral agreement, that is, a request or promise in exchange for an act of payment, it would be asserting an analysis similar to that found in the case of Petterson, supra note 96 - an analysis that has not found much support in Canadian or English courts. Furthermore, if a unilateral framework was superimposed over this fact scenario, it is incredibly unclear as to what the lottery corporation has either promised or requested. If it has promised a ticket in exchange for an act of payment, the ticket promised (based on the claimant's request) is not the ticket that was printed, which begs the question as to what is the correct classification of the nature of the claimant's original request. First, the claimant's request cannot be an invitation to treat because an invitation to treat invites negotiations, which is clearly not contemplated by the lottery scheme. Second, if the claimant's request is nonetheless construed as an invitation to treat, then it begs a second question as to what is the correct classification of the data entry of the ticket numbers by the clerk. Arguably, the data entry cannot be another invitation to treat or an offer because nothing is being invited from or offered to the claimant; rather, it is a communication between an agent and its principal (see discussion on agency in Part IV.B.3 below). Third, it should not be open to the court to simply ignore this important contractual exchange between the claimant and the agent. If the lottery corporation is the offeree, whereby the claimant requests an act, then the lottery corporation did not produce the ticket requested, thus not accepting the claimant's offer. This would place the lottery corporation in the position of the offeror of a new offer, which cannot be the case because the lottery corporation's own pleadings assert that the lottery corporation is the offeree. Regardless, it was clearly the lottery corporation's intention to accept the claimant's request via its agent, the clerk. Logically, then, if a unilateral contract exists at all, the acceptance must have occurred when the clerk entered the numbers into the terminal/requested the quick pick. Given the difficulty in fitting the facts of this case into a unilateral contract, in the view of the authors the factual matrix is better analyzed as a bilateral arrangement. Loto-Québec Statement of Defence, supra note 10 at para. 62.

Ibid.

See Sudbrook Trading Estate Ltd. v. Eggleton, [1983] 1 A.C. 444 at 478 (H.L.)[Sudbrook Trading Estate]:

True it is that the agreement for the sale of land remains executory until transfer of title to the land and payment of the purchase price; but if this is the sense in which the agreement is said not to be complete it is only executory contracts that do require enforcement by the courts; and such enforcement may either take the form of requiring a party to perform his primary obligation to the 
In Gibson v. Manchester City Council, ${ }^{108}$ the English Court of Appeal held that, although the exact moment of "offer," on the one hand, and "acceptance," on the other, were not easily pinpointed, it did not mean that there was no contract between the parties. Lord Denning explains:

To my mind it is a mistake to think that all contracts can be analysed into the form of offer and acceptance. I know in some of the text books it has been the custom to do so: but, as I understand the law, there is no need to look for a strict offer and acceptance. You should look at the correspondence as a whole and at the conduct of the parties and see therefrom whether the parties have come to an agreement on everything that was material. If by their correspondence and their conduct you can see an agreement on all material terms — which was intended thenceforward to be binding — then there is a binding contract in law even though all the formalities have not been gone through. ${ }^{109}$

Therefore, Lord Denning believed that the act which constitutes acceptance need not be immediately apparent in order to create a contract. While it is true that the Court of Appeal's decision in Gibson was overruled by the House of Lords, ${ }^{110}$ the same concept has been used in what is commonly known as the "battle of the forms." ${ }^{.111}$ Under a battle of the forms application, there is terminology to assess what terms should apply. These include the "first blow," "last shot," and "shots from both sides." In cases where the court determines that the shots from both sides approach should apply, it is essentially saying that both parties have agreed to the material terms even though neither one has clearly accepted the offer of the other. This will particularly be the case when dealing with standard form contracts. ${ }^{112}$ That being said, many, though not all, Canadian courts still exhibit a tendency to adhere to the more traditional principle, that is, that acceptance must be "absolute and unequivocal."113

In this case, the parties had agreed to all the material terms of the contract at the moment that the claimant requested the tickets and had both the ability and willingness to pay for the tickets so requested. There was nothing left to be negotiated as between the parties.

Therefore, if the approach advocated by the Court of Appeal in Gibson and Lord Denning in Butler (as well as its progeny) ${ }^{114}$ were adopted by a court in a lotteries case, this could lend significant support to the claimant's case. In other words, as long as the parties agreed on the relevant terms of the contract, determining who the offeror was and who accepted the offer

other party under it (specific performance) or, if he has failed to perform a primary obligation, of requiring him to perform the secondary obligation, that arises only on such failure, to pay monetary compensation (damages) to the other party for the resulting loss that he has sustained. [1978] 1 W.L.R. 520 (C.A.) [Gibson].

Ibid. at 523-24; Loto-Québec Statement of Defence, supra note 10 at para. 62.

Gibson v. Manchester City Council, [1979] 1 W.L.R. 294 (H.L.).

See Butler Machine Tool Co. Ltd. v. Ex-Cell-O Corp. (England) Ltd., [1979] 1 W.L.R. 401 (C.A.) [Butler].

See Cariboo-Chilcotin Helicopters Ltd. v. Ashlaur Trading Inc., 2006 BCCA 50, 222 B.C.A.C. 79 at paras. 18-21.

See General Refractories Co. of Canada v. Venturedyne Ltd., [2002] O.J. No. 54 (Sup. Ct. J.) (QL) at para. 85, citing Dawson, supra note 101. See also Sherwood v. Triad Industries Inc., [2003] O.J. No. 4668 (Sup. Ct. J.) (QL). For further discussion regarding Canadian courts' recourse to the shots fired on both sides approach, see Mary J. Shariff \& Kevin Marechal de Carteret, "Revisiting the Battle of the Forms: A Case Study Approach to Legal Strategy Development” (2009) 9 Asper Journal of International Business and Trade Law 1 at 24, online: Berkeley Electronic Press <http://works.bepress.com/cgi/view content.cgi?article=1000\&context=mary_shariff $>$. See generally Shariff \& Marechal de Carteret, ibid. 
may not be that important as long as it is clear that the agreement has occurred. In this case, the crucial aspect is that the relevant agreement was formed prior to the 9:00 p.m. deadline.

However, even if the more traditional approach is taken, whereby unequivocal acceptance must be identified, there is still an argument to support the position that the lottery player is accepting the lottery corporation's offer when demonstrating a willingness to pay. The fact that the ticket is printed after does not necessarily indicate that the contract has not yet been formed, as Canadian courts often permit the addition of terms subsequent to formation through industry familiarity or when there is a prior course of dealings. ${ }^{115}$

Accordingly, in this case, the claimant's prior course of dealings and industry familiarity support the argument that formation occurred prior to the relevant deadline, with the subsequent addition of the unknown numeric terms, in accordance with the reasonable expectations of the parties. The unilateral change to the date by the lottery corporation as evidenced by the ticket, however, would not, in most cases, have formed part of the prior course of dealings between the parties and, furthermore, would not be included in the terms due to the express or implied objection by the claimant. ${ }^{116}$ As discussed further below, the "game break" - the break between lottery games where no further ticket requests can be entered (but tickets requested prior to the game break will be printed for the draw) until the lottery terminal reopens (a fairly standard practice in Canadian lotteries operations) — was not in place in Quebec at the time of the Ifergan facts. If it had been in place at the time, the claimant's predicament could not have arisen.

\section{The AgREEMENT Is SufFiCIENTLy CERTAIN}

A contract cannot be formed until the terms are sufficiently certain, so that the parties are objectively clear as to what was agreed. ${ }^{117}$ Uncertainty as to the essential elements of the contract will render the contract unenforceable. In this case, an uncertainty argument might be advanced by tying it to the fact that the winning numbers chosen by the computer were not known to the parties until they were selected by the computer. ${ }^{118}$ In the view of the authors, however, undue focus on the unknown numbers obscures the simple reality that, insofar as both parties are concerned, the actual numbers ultimately chosen by the computer are irrelevant to the contract made. In fact, case law supports the proposition that as long as there is "machinery" and/or a formula, the application of which will render the agreement certain, then the agreement will not fail for uncertainty and will be enforceable. ${ }^{119}$

Clearly, in this case, as is the case with all quick pick scenarios, the parties obviously agreed that the lotteries computer (the machinery) would be the means of resolving any

See e.g. Tywood Industries Ltd. v. St. Anne-Nackawic Pulp \& Paper Co. Ltd. (1979), 25 O.R. (2d) 89 (H.C.J.); Guiliani v. Invar Manufacturing (2007), 52 C.P.C. (6th) 129 (Ont. Sup. Ct. J.). For detailed discussion, see ibid. at 34-36.

May \& Butcher Ltd. v. The King, [1934] 2 K.B. 17 (H.L.).

See Loto-Québec Statement of Defence, supra note 10 at paras. 68-69.

See e.g. A.G. v. Barker Bros. Ltd., [1976] 2 N.Z.L.R. 495 (C.A.); Sudbrook Trading Estate, supra note 107. 
uncertainty with respect to the ticket numbers. Thus, any argument attempting to rely on the uncertainty of the numbers must be carefully assessed with this reality in mind. ${ }^{120}$

The very nature of the automated number selection process (the quick pick process as opposed to the personal selection of numbers by the player) is such that a reasonable person would believe that the claimant wanted to have an opportunity to win in a particular lottery drawing, but did not particularly care what numbers were generated in order to provide this opportunity.

Thus, in the view of the authors, the fact that the particular sequence of numbers is unknown to both parties should in no way impact the formation or certainty of the agreement. Again, the relevant terms of the contract are that, in return for the promise (or willingness) to pay, the lottery player is promised an opportunity (chance) at winning a particular jackpot prize, as well as any subsidiary prizes offered by the particular lottery corporation involved. This interpretation is consistent with the reasonable expectations of the parties to a quick pick arrangement.

\section{THE BREACH INVOLVES A LOSS OF CHANCE}

\section{a. General Considerations}

It is a central principle of contract law that, where there has been a breach of contract, the court seeks to place the non-breaching party in the position they would have been in had the contract been carried out. ${ }^{121}$ A lottery corporation could argue that had the ticket been issued for the earlier draw, it might not have been a winner, and therefore no damages arise in the result. Notwithstanding the uncertainty arguments discussed above ${ }^{122}$ and aside from technical arguments that may be available based on how the computer generates random numbers, there are additional arguments available to the claimant.

Breach of contract damages are those that can fairly and reasonably be considered to arise naturally from the breach of contract, or those supposed to be within the reasonable contemplation of the parties at the time they made the contract. ${ }^{123}$ Furthermore, the defaulting party is only liable for the consequences if, at the time of contracting, they ought to have reasonably contemplated them as a "slight possibility." 124

When the breach involves a "loss of chance" in contract law, the loss of chance is to operate "first and foremost" as a type of damage, ${ }^{125}$ but because loss of chance deals with future events, it must also address the notion of certainty. Future events all come down to the degree of certainty of whether or not they will happen, so it is about possibilities, not balance

"A contract is complete as a contract as soon as the parties have reached agreement as to what each of its essential terms is or can with certainty be ascertained: for it is an elementary principle of the English law of contract id certum est quod certum reddi potest”: Sudbrook Trading Estate, ibid. at 479. McCamus, supra note 87 at 813.

See discussion in Part IV.A.4.

Hadley v. Baxendale (1854), 9 Exch. Rep. 341, 156 E.R. 145 at 147-48 (Ex. Ct.) [Hadley].

Parsons (Livestock) Ltd. v. Uttley Ingham \& Co. Ltd., [1978] 1 Q.B. 791 at 804 (C.A.); see also Asamera Oil Corporation Ltd. v. Sea Oil \& General Corp., [1979] 1 S.C.R. 633 [Asamera].

Laferrière v. Lawson, [1991] 1 S.C.R. 541 at 559. 
of probabilities. Interestingly, in discussing the issue of loss of chance, Stephen Waddams writes:

\begin{abstract}
Suppose that the plaintiff holds a lottery ticket that gives a ten per cent chance of winning a prize of $\$ 1,000$ and the defendant in breach of a legal duty destroys the ticket so that the plaintiff is deprived of the opportunity of participating in the draw. More probably than not the plaintiff would not have won even if the defendant had fulfilled his duty, and yet it would be odd to conclude that the plaintiff has lost nothing by the defendant's wrong. If the plaintiff can recover no damages for the loss of a ten per cent chance, the same reasoning would seem to deprive the plaintiff of damages also in the case of the loss of a fifty per cent chance. $^{126}$
\end{abstract}

Generally speaking, therefore, in order to recover damages for breach of contract, the claimant must establish three elements. These are, first, that on a balance of probabilities the breach of contract resulted in the damages claimed (in this case, the breach of contract is the non-delivery of the ticket requested); ${ }^{127}$ second, that the damages are not too remote, that is, that they were reasonably foreseeable to the lottery corporation when the contract was made (in this case, it is reasonably foreseeable that the damage could result to the player if they were not granted the thing bargained for, that is, the opportunity to be a valid player in the particular draw with a particular jackpot); ${ }^{128}$ and third, the quantum of loss with a reasonable degree of certainty (in this case, the quantum is certain, one half of \$27 million). ${ }^{129}$

\title{
b. Loss of Chance Case Law
}

Chaplin was one of the first English cases to elaborate on the concept of loss of chance. ${ }^{130}$ In Chaplin, the defendant theatre director placed a newspaper advertisement asking for young women to submit applications for a chance to secure an acting job. The plaintiff had submitted an application and was selected to come in for an interview. The director sent a letter to the address the plaintiff had provided instructing her to appear at a certain place and time for the interview. The plaintiff, however, was out of town for a period of time and did not receive the letter. After some time, the letter was re-addressed and received by the plaintiff. By this time, however, it was much too late to make the appointment. The plaintiff sued the defendant for breach of contract for his failure to give her an opportunity to present

S.M. Waddams, The Law of Damages, 3d ed. (Toronto: Canada Law Book, 1997) at para. 13.270. McCamus, supra note 87 at 847-49.

Hadley, supra note 123 at 147-48.

Ibid. See also Chaplin v. Hicks, [1911] 2 K.B. 786 (C.A.) [Chaplin]; Ratcliffe v. Evans, [1892] 2 Q.B.

524 at 532-33 (C.A.); Mallett v. McMonagle, [1970] 1 A.C. 166 at 176 (H.L.) per Lord Diplock:

In determining what did happen in the past a court decides on the balance of probabilities.

Anything that is more probable than not it treats as certain. But in assessing damages which depend upon its view as to what will happen in the future or would have happened in the future if something had not happened in the past, the court must make an estimate as to what are the chances that a particular thing will or would have happened and reflect those chances, whether they are more or less than even, in the amount of damages which it awards.

See also Davies v. Taylor, [1974] 1 A.C. 207 at 213 (H.L.):

If the evidence shows a balance in favour of [something] having happened then it is proved that it did in fact happen.... You can prove that a past event happened, but you cannot prove that a future event will happen and I do not think that the law is so foolish as to suppose that you can. All that you can do is to evaluate the chance. Sometimes it is virtually 100 per cent.: sometimes virtually nil. But often it is somewhere in between. And if it is somewhere in between I do not see much difference between a probability of 51 per cent. and one of 49 per cent.

See also Houweling Nurseries Ltd. v. Fisons Western Corp. (1988), 49 D.L.R. (4th) 205 (B.C.C.A.); Asamera, supra note 124.

Chaplin, ibid. 
herself at the interview. ${ }^{131}$ The defendant argued that an award of loss of chance damages would be inappropriate because such damages were both too remote and unassessable. The Court of Appeal held in favour of the plaintiff, stating that

[t]he very object and scope of the contract was that the plaintiff should have the chance of being selected by the defendant for one the theatrical engagements he offered, and his refusal to fulfil his part of the contract is the breach of contract complained of. Damages are, therefore, a fair compensation to the plaintiff for being excluded from the limited class of candidates. ${ }^{132}$

On this basis, the Court held that damages for loss of chance flowed directly from the breach, and dismissed the defendant's remoteness argument. Another key element was that there was clearly an injury given that the plaintiff was part of a limited class of competitors.

This case has been approved and applied by both the Supreme Court of Canada ${ }^{133}$ and the Ontario Court of Appeal. ${ }^{134}$ In Eastwalsh Homes Ltd. v. Anatal Developments Ltd., ${ }^{135}$ the Ontario Court of Appeal provided principles to be used in loss of chance cases. First, the burden rests on the plaintiff to show, on a balance of probabilities, that the breach caused a loss to the plaintiff. Where it is clear that the breach caused the loss, it is irrelevant that the loss is difficult to assess. ${ }^{136}$ In such a case, the concept of loss of chance is then at issue. The court will estimate the plaintiff's chance of obtaining a benefit had the contract been performed. Proof of a lost chance is insufficient unless it is also shown that the chance constitutes some reasonable probability of realizing an advantage of substantial monetary value. $^{137}$

With respect to calculation, the court must discount the value of the chance by the improbability of its occurrence. In other words, if there is a root harm compensable for $\$ 100,000$, but there was only a 40 percent probability that the loss would have in fact occurred, then the plaintiff is entitled to $\$ 40,000$ in compensation. ${ }^{138}$

In Kinbauri Gold Corp. v. Iamgold International African Mining Gold Corp. ${ }^{139}$ the Ontario Court of Appeal affirmed the trial court's decision, which indicated that the Court would consider the following in determining the value of a lost chance: (1) the number of contingencies on which the chance depends, and (2) the likelihood of the contingencies being

The case proceeded on the basis that there was both a contract and a breach of it (ibid. at 226). However, the defendant advertised a contest in a newspaper. The terms of the advertisement indicated that those who were chosen would have an opportunity to interview and, in turn, have a chance to be selected as a finalist. The defendant failed to give the plaintiff a reasonable opportunity to be interviewed and thus broke the terms of the contract. Ibid. at 229 [emphasis added].

133 Kinkel v. Hyman, [1939] S.C.R. 364; Webb \& Knapp (Canada) Ltd. v. Edmonton (City of), [1970] S.C.R. 588 [Webb].

Multi-Malls Inc. v. Tex-Mall Properties Ltd. (1981), 37 O.R. (2d) 133 (C.A.) [Multi-Malls]. An application for leave to appeal from this decision was dismissed by the Supreme Court of Canada: [1982] 1 S.C.R. xiii.

(1993), 12 O.R. (3d) 675 (C.A.).

Webb, supra note 133 at 601.

Ibid. at 600-601. "Reasonable probability" was also discussed and applied in Bailey v. Dixon, [1991] B.C.J. No. 1066 (S.C.) (QL); Central Guaranty Trust Co. v. Patterson Kitz (1995), 139 N.S.R. (2d) 331 (S.C.).

Vaughan Black, “Ghost of a Chance: Gregg v. Scott in the House of Lords” (2005) 14:2 Health L. Rev. 38 at 38. 
satisfied in the plaintiff's favour. Nevertheless, the Court acknowledged that this quantification of the plaintiffs' damage would be a speculative exercise.

The following scenario, based on the facts in Multi-Malls, ${ }^{140}$ illustrates the concept in the context of a breach of contract:

[A] defendant who breaches a contractual obligation to seek zoning or planning approval for a piece of real property might claim that the plaintiff has suffered no loss because, even had the obligation been performed, the approval would, on the balance of probabilities, not have been granted. Canadian courts have acknowledged that in such cases damages may be awarded by valuing the loss of the chance that the relevant zoning or planning authority would have given the approval had the defendant sought it. ${ }^{141}$

\section{c. Loss of Chance Argument}

Accordingly, relying on the case law referred to, a loss of chance argument for the claimant's case might run as follows:

- $\quad$ The very object and scope of the agreement between the claimant and the lottery corporation was to give the claimant the chance of being selected as a prize winner;

- The refusal of that chance is the breach of the contract in respect of which damages are claimed as compensation for the exclusion of the claimant from the limited class of competitors;

- $\quad$ The class is limited to those players who had done everything within their power to participate in the particular lottery draw;

- $\quad$ The breach was the breach of the lottery corporation;

- $\quad$ There were no other intervening factors responsible for the loss of the claimant;

- $\quad$ The loss of chance flowed directly from the breach;

- Expulsion from a limited class of competitors is an injury that deserves compensation and the claimant is entitled to have his loss estimated;

- Difficulty in calculation or assessment is no answer to the claim;

- An award of only nominal damages is insufficient;

- The court is tasked with estimating the claimant's chance of obtaining a benefit had the contract been performed; and 
- There is ample proof (the printout with the corresponding winning numbers and the first printout identifying his request before 9:00 p.m.) that the chance constitutes a reasonable probability that the claimant would have realized an advantage of a substantial monetary value.

In fact, given the post-breach reality, the claimant should be awarded damages equal to the dollar value that would be awarded in respect of the root harm (\$13.5 million) discounted by the probability that the harm would have happened in any event (nil). ${ }^{142}$

Asserting the contractual case on the basis of loss of chance is crucial to the claimant given the lotteries case law, which, as discussed, requires the claimant to be able to prove that he has a "winning" ticket. The claimant does not have a winning ticket as defined by the regulations. Thus, it is essential for the claimant to demonstrate contractual breach separate from any contractual breaches that would be governed by the regulatory regime. It is the authors' view that loss of chance may be one such breach.

\section{d. Substituted Tickets Did Not Provide Equivalent Chance}

As described above, McCorkell demonstrates how a court may be disinclined to permit a breach of contract when the player has been provided with a different chance at winning in substitution of the original ticket. Again, the notion here is that because the substitution provides the player with an equivalent chance at winning, the player has suffered no compensable loss of chance. Assuming the McCorkell perspective on chance is accurate there are some significant distinctions between the facts in McCorkell and those in the claimant's case to suggest that the claimant may have indeed suffered a compensable loss of chance.

For example, in McCorkell the player requested, and was provided with, three chances in the same draw, notwithstanding that one of the number combinations had been erroneously substituted. What was significant to the Court was that the player's chances of winning were

As mentioned above, the authors have chosen to refrain from pursuing a line of reasoning based on tort law and, in particular, the law of negligence. However, loss of chance plays out in the negligence context. As one author has put it:

The doctrine holds that a claimant occasionally should be permitted recovery despite failing to satisfy the usual burden of establishing on a balance of probabilities that the tortfeasor's conduct caused him to suffer a loss. If able to prove that the defendant's actions prevented him from enjoying a significant opportunity (beyond the de minimis range) to gain a benefit or avoid a detriment, the plaintiff may be granted relief, discounted to reflect the likelihood of the relevant chance.

Mitchell McInnes, “Causation in Tort Law: Back to Basics at the Supreme Court of Canada” (1997) 35 Alta. L. Rev. 1013 at 1032 [emphasis added]. Accordingly, if a negligence argument were to be made, it might run as follows: the lottery corporation had a duty of care to the claimant and all players of the Super 7. The standard of care is that of a reasonable lottery corporation. Loto-Québec breached the standard of care by not having a game break/closing time (between five and ten minutes) between the current draw and the next draw in order to properly delineate between ticket requests for the current draw from those for the next draw. This conduct caused the claimant to suffer a loss; that is, the lottery corporation's actions prevented him from enjoying a significant opportunity to gain a benefit in the amount of $\$ 13.5$ million. The lottery numbers provided matched the lottery numbers drawn and, accordingly, the likelihood of him winning was 100 percent but for the lottery corporation's negligence. For further detailed and recent discussion of loss of chance doctrine in the U.K., see Samuel Townend, "Certainty and Loss of a Chance in the Assessment of Damages (Or The Uncertainty: Loss of Chance)" (2005), online: Keating Chambers <http://www.keatingchambers.co.uk/resources/publications/2005/st_ certainty_and_loss.aspx>. 
not diminished. He still received three chances, and, according to the Court, any of those number combinations possessed the same odds of winning. In the claimant's case, however, he requested ten chances for a particular draw, but only received five. It is a basic tenet of probability theory that the more tickets that are bought for the same draw, the greater the chance of winning. ${ }^{143}$ A substitution for five chances in a second draw is not an equivalent substitution, and thus points towards a breach of contract.

Additionally, in McCorkell, the player did not receive the ticket reflecting his selection because of his own negligence. In the claimant's case, the ticket did not reflect the correct date due to the mischief of the lottery corporation's computer. The claimant was hardly negligent in making his ticket request before the draw deadline for that particular jackpot ${ }^{144}$ and, furthermore, could not have done anything to correct the lottery corporation's failure to provide him with all ten chances for that draw. Thus, if it is the case that the claimant, through no fault of his own, did not receive an equivalent substituted chance, then there is an even stronger argument to suggest breach of contract based on a loss of chance.

It should be noted that the Court in McCorkell did not expressly articulate that a substituted equivalent chance avoided what might otherwise have been a breach of contract. Therefore, it is incumbent upon the courts (or, preferably, the legislature) to provide a coherent explanation as to when and where a lottery contract is formed in order to establish, among other things, whether a breach has occurred and whether a substitution is even necessary to avoid a breach in the first place. In order for the claimant to be successful on the basis of having not received an equivalent substitution (assuming the lottery corporation has amended its pleadings to include this argument), he will have to demonstrate the formation of a contract prior to his acceptance of the substituted chances. Otherwise, he might be considered as having affirmed the substitution. ${ }^{145}$

The notion of equivalent substitution aside, should the claimant nonetheless be prevented from a breach of contract remedy on the argument that if the substituted ticket won on the second draw, the lottery corporation would be strictly obligated to pay out the prize, even though this was not the draw in which the claimant had intended to participate? The concern raised here is that the claimant could utilize the five chances for the later draw, even though he did not request them for that draw, while at the same time possessing a potential claim for breach of contract damages for the five chances he was not given in the previous draw arguably, increasing his number of "chances" by using the same ticket across two drawings.

McCorkell provides perhaps the clearest illustration of this concern. In McCorkell, the player was given three chances at a draw. If one of the number combinations came up, he would unquestionably be a winner. If, however, a number combination on the non-issued ticket that he bargained for was a winner, he would be entitled to damages for breach of contract. According to the Court, this would be an untenable result. The claimant's fact scenario, however, differs in that he cannot manoeuvre between the dual options as readily.

Norbert Henze \& Hans Riedwyl, How to Win More: Strategies for Increasing a Lottery Win (Natiek, Mass.: A K Peters, 1998) c. 3 at 14ff.

See policy discussion concerning how lottery advertising of an increasing jackpot encourages last minute ticket purchases in Part V.C, below, and supra note 93 and associated text.

See discussion on affirmation in Part IV.B.1, below. 
His tickets span across two different drawings: five chances in the earlier draw, and five chances in the later draw. He would first have to wait until the second draw plays out. If he utilizes the five chances for the later draw, all five chances would have to lose in order for him to resort to a breach of contract argument for the earlier draw. He would then apply the five chances retroactively via a breach of contract argument back to the first draw. At this point, he would be arguing for damages for the winning number combination on the ticket he was not provided for the earlier draw, and the relevant winning numbers would have to have been drawn in that earlier drawing. Under these circumstances, a player is going to raise breach of contract in the earlier drawing. Having done so, they will be pre-empted from applying the ticket to the later drawing.

The lottery corporation will have grounds to refuse to honour the ticket for the later draw because the chances have been applied to the earlier draw by virtue of the player's own admission, the ticket terminal operator's evidence, and from the information registered in the terminal at the time of the ticket request. It would not be arbitrary or unreasonable for the lottery corporation to resist honouring the tickets for the second draw on that basis. In other words, once the evidence is clear that the chances were intended to be applied to the earlier drawing, the lottery corporation has grounds to resist any attempt by the player to use those chances to win in the second draw.

Without question, in order to maintain the integrity of lottery games, there must be certainty in ticketing. As described above in relation to Murphy and Karagiannis, the rules and regulations requiring strict proof are aimed at preventing particular types of mischief. When, however, unique factual circumstances arise that are clearly not anticipated by the rules and regulations, the rules and regulations are ambiguous and are to be construed contra proferentem. Additionally, once a case like the claimant's has been decided, it is always open to the lottery corporation to amend its rules and regulations and processes to provide clarity and certainty regarding contract formation, simultaneous ticket requests, the discretion to refuse requests, the discretion to refuse to issue tickets after a request, and the substitution of tickets.

\section{SUMMARY OF ARGUMENT WITH LOTTERY CORPORATION AS OFFEROR}

Based on the five considerations set out above, a potential argument in favour of the claimant might run as follows:

- The lottery corporation (the offeror) made an offer to give a chance at winning a $\$ 27$ million jackpot if a ticket is purchased prior to the 9:00 p.m. deadline;

- The claimant (the offeree) accepted that offer when he requested, prior to the deadline, two tickets to have a chance at that draw;

- The contract crystallized at that point because it is a bilateral contract (a promise for a chance in return for a promise to pay) and there was nothing left to be negotiated. All that was left to perform were the mechanical acts of (1) issuing/ printing the ticket and (2) acceptance of payment; 
- $\quad$ Neither the issuing/printing of the tickets nor the act of payment can be construed as acceptance by the claimant because the performance of these acts is controlled by the offeror. These acts relate to the performance of the agreement, not the formation of the agreement;

- The contract does not fail for uncertainty because the jackpot is certain and a set of randomly generated numbers is also certain;

- $\quad$ This interpretation is consistent with the reasonable expectations of the parties;

- The lottery corporation was in breach of the agreement when it did not provide the opportunity bargained for (that is, a chance to win the 23 May 2008 drawing of the Super 7);

- $\quad$ The claimant's chances were diminished because of that error;

- $\quad$ Even if the claimant cannot rely on the representations of the clerk, the lottery corporation's agent, the claimant requested the tickets prior to the deadline set by the lottery corporation in accordance with its rules and regulations; and

- $\quad$ The claimant's damages for the breach are the loss of chance from being expelled from a limited class of competitors, with his loss estimated at \$13.5 million.

\section{B. LotTery Corporation as Offeree, LotTery Player As OfFeror}

\section{PRELIMINARY CONSIDERATIONS}

Above, the authors set out their view that the adhesion nature of the contract between the player, on the one hand, and the lottery corporation, on the other, means that the lottery corporation is the offeror in such circumstances. However, the authors recognize that one could make an argument (as Loto-Québec has done in its pleadings) that the lottery corporation is the offeree. ${ }^{146}$

This is based on the discretion of the lottery corporation to refuse to issue a ticket. In the view of the authors, there are several problems with this argument. First, the discretion to refuse to issue tickets is set out in the regulation. However, it does not seem likely that this contemplated a refusal to issue tickets after accepting the wager. Second, on these facts, there was no allegation that the discretion was being exercised. The term "discretion" itself implies the exercise of discretion by a human being, not a machine. The decision made here was not based on discretion. The computer did not exercise discretion. Third, if there were discretion, it was not exercised to not accept the wager. The agent punched in the request. This is clearly an acceptance of the wager, not an exercise of discretion to not accept the wager. Fourth, the case law requires the discretion to be exercised fairly and reasonably, not arbitrarily. If this is to mean anything, it must mean, at least, that the discretion cannot be exercised after the lottery drawing for which the ticket was meant to be issued. To do otherwise would be to give the corporation the discretion to avoid paying any winning ticket. Therefore, it seems clear that the discretion must be exercised before the drawing, if it is to be exercised at all. Unless and until such discretion is avowedly exercised by the corporation, it does not affect any contract entered into between the claimant and the lottery corporation. Fifth, even if the discretion could be exercised ex post facto, the case law dealing with this discretion is based on a decision to disallow a wager on bona fide policy grounds that are designed to protect the integrity of the lotteries scheme as a whole. There is nothing to indicate that allowing the claimant's ticket to stand as valid (whether it won or not) would undermine the lotteries scheme as a whole. Sixth, if there is no policy reason to justify the refusal to accept the ticket, such a refusal will be subject to a duty of care. If this is the case, then an argument could be made that the lottery corporation was negligent in not setting up a game break so as to ensure that all parties were 
This argument is made on the basis that (1) the advertising was a mere invitation to treat, (2) the lottery corporation has the discretion to refuse to accept wagers or issue tickets, and (3) the first action to result in the contract (that is, the offer) came from the claimant in the form of the request for two tickets.

In this case, the relevant questions are:

- What constitutes acceptance on the part of the lottery corporation?

- $\quad$ Could acceptance by the lottery corporation have occurred prior to the issuing of the printed ticket?

- $\quad$ Regardless of any technical requirement to specifically identify offer and acceptance, could the contract have been formed prior to the issuing of the ticket?

Loto-Québec argues that acceptance occurred after the deadline, when the ticket request was registered and processed by the lottery corporation's central computer. ${ }^{147}$ This position, however, lacks two key contractual elements: intention and consideration.

First, it was clear that the intention of both parties was to contract for the sale and purchase of two tickets for the 23 May 2008 draw. Therefore, the contract supposedly created is reflective of the intention of neither the claimant nor the store clerk, the only representative agent of the lottery corporation. Under traditional contract law doctrine, if the document does not reflect the intention of the parties, it cannot form the basis of the contract.

Knowledge of consideration is also lacking. The claimant walked into the store and requested a ticket for a lottery game with a top jackpot prize of \$27 million; the subject matter of the contract was certain, that is, $\$ 27$ million. The claimant received a ticket not only for the wrong date, but also for an unbargained for and, as it turns out, lower jackpot. Thus, the ticket received by the claimant was less valuable to him than the one for which he had in fact bargained.

Consideration is defined as something of value, in the eyes of the law, moving from the promisee (but not necessarily to the promisor) in return for the promisor's promise. ${ }^{148}$ It is true that courts will generally not inquire into the adequacy of consideration. However, in the claimant's case there is no allegation that the consideration is inadequate. Rather, this is a case of one side unilaterally altering the consideration to be received by the other. Since the consideration (whether sufficient or not) was altered, there was no consensus ad idem, and a significant monetary opportunity was lost.

aware of what was being purchased. Finally, in other Canadian jurisdictions, the regulations set out the delay time that could be expected. The Quebec regulations do not inform the public of this delay. Yet, the lottery corporation relies on that delay as a reason to deny a ticket for a given draw to the claimant. Again, this raises the spectre of a negligence based claim in tort. 
The lottery corporation will be fully aware of the fact that the amount of the top jackpot prize affects consumer behaviour with respect to the purchase of tickets. In fact, most of the day-to-day advertising of a given lottery includes the publication and announcement of the growing jackpot prize right up until the relevant draw. Yet, the lottery corporation appears to assert a right to adhere to a contract where it has accepted a wager ${ }^{149}$ and then unilaterally decides to issue a ticket for a different draw. This alters both the quality and subject matter of the ticket on which the lottery corporation's own advertising is based (that is, the top jackpot prize of a particular draw). The lottery corporation should not be allowed to assert that a ticket in a draw with a top jackpot prize of $\$ 27$ million is equivalent to one with a top jackpot prize of $\$ 4$ million, for example. If the two are not equivalent, the substitution of one for the other cannot form the basis of a contract. Since both sides seem to be arguing that there is a contract for the purchase of the lottery ticket, the solution of simply voiding the ticket seems untenable. If this is so, this leaves only the 23 May 2008 draw as consideration for the contract created.

Of course, the obvious counter-argument here is that the claimant was not obligated to purchase the revised ticket ${ }^{150}$ and that it was the revised ticket itself that constituted the offer from the lottery corporation, which, despite its date, the claimant accepted after the 9:00 p.m. deadline. ${ }^{151}$ This argument implies that the claimant affirmed the purchase of the ticket despite it being dated for the following week's draw. Affirmation, however, presupposes that the claimant had the chance to obtain what it was that he was originally bargaining for, and chose to accept something else in its stead. ${ }^{152}$ In reality, the claimant did not have a choice. He could not get what he bargained for because his chance was already lost. Thus, his failure to complain cannot logically be used against him when arguing with the clerk could not have gotten him what was bargained for. In the view of the authors, focusing on this indisputable fact might assist in resolving the crux of this contractual dilemma.

\section{SUMMARY OF ARGUMENT WITH LOTTERY CORPORATION AS OFFEREE}

With the above in mind, and accepting the lottery corporation as the offeree, the argument runs as follows:

- $\quad$ The claimant requested two tickets. This constituted an offer;

See By-law respecting forecast contests and numbers games, supra note 31, s. 9.

See Ifergan Discovery, supra note 17 at para. 91 , where the clerk asks the claimant if he wants the ticket to which he responds, "I purchased it, it’s mine."

151 See Loto-Québec Statement of Defence, supra note 10 at para. 62.

152 See Ennis v. Klassen (1990), 70 D.L.R. (4th) 321 (Man. C.A.) [Ennis]. Unlike in Ennis, in the claimant's case there were no "steps on the path to rescission" (at 330) that the claimant could have taken, other than cancelling the contract. If the only choice is to take what the lottery corporation has given or have no contract at all, the decision to do either is not an affirmation because such an approach would mean that there would never be a contract related to what was intended by the parties, that is, an opportunity in the lottery drawing of a particular date. Also, affirmation is a response to an innocent misrepresentation that induced a contract. The argument here centres on breach, not inducement. Breach of contract is compensated for by legal remedies (such as damages), rather than equitable remedies (such as rescission without damages). Therefore, the concept of affirmation (a response to the equitable remedy of rescission) does not apply. See also the discussion of equivalent ex ante substitution at Part IV.A.5.d, above. 
- The behaviour of the lottery corporation's agent (entering the request into the computer terminal) was consistent with accepting the claimant's offer. This clearly occurred before the 9:00 p.m. deadline. The contract was formed at that time;

- The inability of the lottery corporation to generate a ticket reflective of the parties' bargain is a breach of the contract bargained for and entered into between the parties;

- Given the strict regulatory regime governing the definition of a "winning” ticket, which clearly delineates the roles and responsibilities of the parties, the lottery corporation was in breach of the contract when it failed to produce the requested ticket in a timely manner;

- The representations of the authorized lotteries retailer reinforce this conclusion;

- This contractual breach by the lottery corporation is then a state of affairs from which it now seeks to benefit. It seeks to not pay the claimant based on the fact that its computer terminal did not produce the ticket at the relevant time; ${ }^{153}$

- $\quad$ This prevented the claimant from being included in a limited class of competitors for a \$27 million jackpot (see loss of chance argument above at Part IV.A.5.c); and

- The claimant's later purchase of a different ticket is simply irrelevant to this earlier contractual breach.

It is clear that the lottery regulations grant the lottery corporation the discretion not to accept wagers. However, it is far from clear that the lottery corporation has the discretion to first accept a wager (the plain and ordinary meaning of the actions of the agent), but then refuse to issue a ticket. Had that been the intention of the regulation, it should have read: "the Company may, at its discretion, refuse to accept wagers or issue tickets.” Instead, it reads: "[t]he Company may, at its discretion, refuse to accept wagers and to issue tickets." ${ }^{154}$ In other words, in the view of the authors, the regulations identify that the "acceptance of a wager" occurs when the request is taken, and the regulations do not give the lottery corporation the discretion to refuse to issue a ticket once the wager has been "accepted."

To this point, the authors assert that payment is performance rather than a part of contract formation. In its defence, the lottery corporation claims that the contract for the purchase of the tickets was formed only when the claimant purchased the ticket; that is, when money

[T]he only thing that has prevented the machinery provided by the option clause for ascertaining the fair and reasonable price from operating is the lessors' own breach of contract in refusing to appoint their valuer. So if the synallagmatic contract created by the exercise of the option were allowed to be treated by the lessors as frustrated the frustration would be self-induced, a circumstance which English law does not allow a party to a contract to rely on to his own advantage. 
changed hands. ${ }^{155}$ Admittedly, there is case law to support the idea that a contract for the purchase of goods is not formed until consideration is delivered to the seller. ${ }^{156}$

However, there is also case law to suggest that even in the context of self-service stores, ${ }^{157}$ where it is clear that the purchase was destined to be completed and one of the parties would be harmed by the delay in formation, the contract may be formed earlier than at the transfer of consideration. ${ }^{158}$ This analysis, of course, is highly fact dependent. The court may even refuse to recognize a transfer of property, despite the passage of consideration, in an appropriate context. ${ }^{159}$

Hence, there are arguments on both sides of this issue. How is a court to decide? It has often been said that the best way to determine the intention of the parties at the time of contract formation is by looking at the actions taken pursuant to the contract that was created. ${ }^{160}$ In this case, the assertion of the lottery corporation is that the contract between the corporation and the claimant was made at the time of payment. Since payment was tendered after the deadline, the ticket at issue was properly excluded from the 23 May 2008 draw.

The facts here, however, do not support the lottery corporation's contention. After all, the money only passed to the store clerk once, in order to pay for both tickets. If the lottery corporation's contention were correct, both tickets would be purchased at the same time. Yet, the lottery corporation's own treatment of the tickets suggests that the payment of the money in return for the tickets does not form the contract. If there was only one purchase, then both tickets should be for a single drawing. They are not. Therefore, it cannot be correct that the passage of money was intended to be the final step in contract formation because the treatment of the tickets by the very party that would seek to assert such a position is entirely inconsistent with it.

In the authors' view then, payment was not a part of contract formation. Instead, the authors argue that, even if the lottery corporation is the offeree, the offer is made when the player requests the ticket. The offer is accepted when the agent of the corporation does anything that can only be consistent with an acceptance. Pressing the button to issue the ticket - the "acceptance of a wager" — is such an action. All of this occurred prior to 9:00 p.m.

\section{IS THE CLERK's STATEMENT RELEVANT?}

The short answer, in the view of the authors, is “yes.” This is despite the fact that there is case law to support the idea that representations of the authorized lotteries retailers or agents are not binding on the lottery corporation. ${ }^{161}$ 
It is clear that some sort of agency between the lottery corporation and the authorized lottery outlets exists. After all, the lottery corporation trains and certifies operators, and the retail outlet issues the ticket on behalf of the lottery corporation. ${ }^{162}$ Therefore, there must be an agency relationship between the two. ${ }^{163}$ The question then becomes whether the agent had the authority to make the statement that there was still time to buy a ticket at the time of the claimant's request. There are two basic types of authority: actual authority ${ }^{164}$ and ostensible authority. ${ }^{165}$ Each is potentially available here. Actual authority depends on the relationship between the parties to the alleged agency. In this case, the parties are the lottery corporation, on the one hand, and the authorized lottery retailer, on the other. In contract, ostensible authority depends on the relationship between the alleged principal (the lottery corporation) and the third party (the claimant). If:

(1) the corporation's activities would lead a reasonable person to believe that the agent had certain authority; and

(2) the agent says something that would fall within that authority (if, in fact, the authority had been given); and

(3) there was reliance on the part of the claimant on the words or actions of the agent; and

(4) the reliance was reasonable in the circumstances,

then the principal (that is, the lottery corporation) can be bound by the actions of the agent (that is, the clerk) even though the principal never gave the agent the actual authority to do what was done. ${ }^{166}$

In this case, the activities of the lottery corporation were organized in such a way that the lottery players could not reasonably expect answers to routine questions (such as the one at issue here) from anyone other than the clerk. The fact that employees of authorized lottery retailers receive training from the lottery corporation only reinforces the notion that the attendant is the face of the lottery corporation, at least insofar as the public is concerned. ${ }^{167}$

See e.g. Alberta Gaming and Liquor Commission, Lottery Ticket Centre Policy Handbook at ss. 1.1.3, 1.2.3(a)-(f), 1.3.7, 1.3.12, online: Alberta Gaming and Liquor Commission <http://aglc.ca/pdf/gaming/ gaming_policies/LTC_Policy_Handbook.pdf $>$ [Lottery Handbook]. Given that the retailer is clearly an agent of the lottery corporation (and, as such, would owe a fiduciary duty to the lottery corporation), it seems antithetical to suggest that the retailer is also an agent of the player. Otherwise, when the two (the player and the lottery corporation) come into conflict, the retailer is conflicted as well. In the view of the authors, it is clear that the retailer is the agent for the lottery corporation only throughout the process of ticket purchase and distribution.

See generally Cameron Harvey \& Darcy MacPherson, Agency Law Primer, 4th ed. (Toronto: Carswell, 2009) at 1. See also Lord Denning's discussion on agency in Financings Ltd. v. Stimson, [1962] 3 All E.R. 386 at 388-89 (C.A.). Harvey \& MacPherson, ibid. at 7-16.

Ibid. at 64-80.

Freeman \& Lockyer v. Buckhurst Park Properties (Mangal) Ltd., [1964] 2 Q.B. 480 at 503 (C.A.).

"Concerned as it is with supporting the sales efforts of its retailers, Loto-Québec provides them with the information, tools and training they need to carry out their work effectively, and in so doing, ensures that lottery products are sold in a systematic and effective fashion": Loto-Québec, "Retailers: Nearly 8,700 retailers with online terminal to serve you better," online: Loto-Québec <http://lotoquébec.com/loteries/ nav/en/useful-information/retailers/accueil>. 
At least one of the lottery cases reviewed has indicated that the acts of lottery agents "cannot ... reasonably be relied upon to affect the express instructions to participants or override the basic structure of the game.”168 Several questions then arise. How is a player who is close to the deadline supposed to know what they are buying? The agent is the only person available to the player to answer this very basic question. Furthermore, the delay in receipt by the central computer is not something of which the player can satisfy themself. If not the agent, then who can bind the lottery corporation?

Does it really "override the basic structure of the game" for the agent to acknowledge the reality of the situation, that is, that the player did everything within his power to buy a ticket? In the view of the authors, it does not. If the representative tried to authorize additional tickets that were requested past the deadline, this could override the basic structure of the game. However, on the facts relevant to the claimant's argument, all of the contractual activity was completed prior to the publicly announced deadline of 9:00 p.m. Agency arguments aside, then, the express rules of the game set out a 9:00 p.m. deadline to enter the contest, which the claimant clearly met as proven by the date and time printed on the first ticket that issued from the lottery terminal.

\section{AdDitional CONSIDERATIONS}

\section{A. THE ELECTRONIC COMMERCE AND INFORMATION ACT ${ }^{169}$}

There is some insight to be gained from appreciating the lottery contract in the context of it being an electronic transaction. Specifically, the lottery corporation's argument, that the ticket is not valid until processed by the central computer, is not supported by the ECIA.

Most provinces have passed legislation to deal with the increasing prevalence of contracts created by what are commonly referred to as "electronic documents," that is, documents created by an information system (such as a computer) to make a contract with either an individual or another information system. ${ }^{170}$ The following definitions are used:

\footnotetext{
“electronic" includes created, recorded, transmitted or stored in digital or other intangible form by
} electronic, magnetic, optical or any similar means;

“electronic document” means information that

(a) is electronically recorded or stored in or by an information system, and

(b) can be read or perceived by a person or by an information system; 
“information system” means a system for generating, sending, receiving, storing or otherwise processing electronic documents. $^{171}$

\section{Even more importantly, the following substantive provisions are relevant to this discussion} as well:

20(1) In this section, “ electronic agent” means a computer program or any other electronic means used to initiate an act, or to respond to an electronic document or act, without review by an individual at the time of the act or response.

20(2) A contract may be formed by the interaction of an electronic agent and an individual or by the interaction of electronic agents.

20(3) A contract formed by the interaction of an individual with the electronic agent of another person has no legal effect and is not enforceable if the individual made a material error in the electronic document used in the formation of the contract and

(a) the electronic agent did not provide the individual with an opportunity to prevent or correct the error;

(b) on becoming aware of it, the individual promptly notifies the other person of the error; and

(c) where the individual has received consideration under the contract, he or she

(i) returns or destroys the consideration in accordance with the other person's instructions or, if there are no instructions, deals with it in a reasonable manner, and

(ii) does not benefit materially by receiving the consideration.

21(1) Unless the sender and addressee agree otherwise, an electronic document used in the formation or operation of a contract is sent when it enters an information system outside the control of the sender or, if the sender and addressee are in the same information system, when it becomes capable of being retrieved and processed by the addressee.

21(2) An electronic document used in the formation or operation of a contract is presumed to have been received by the addressee 
(a) when it enters an information system designated or used by the addressee for the purpose of receiving documents of the type sent and is capable of being retrieved and processed by the addressee; or

(b) if the addressee has not designated or does not use an information system for the purpose of receiving documents of the type sent, when the addressee becomes aware of the information or document in the addressee's information system and the information or document is capable of being retrieved and processed by the addressee.

21(3) Unless the sender and addressee agree otherwise, an electronic document used in the formation or operation of a contract is deemed to be sent from the sender's place of business and is deemed to be received at the addressee's place of business.

21(4) For the purpose of subsection (3),

(a) if a person has more than one place of business, the person's place of business is the one that has the closest relationship to the contract to which the electronic document relates or, if that cannot be determined, the person's principal place of business; and

(b) if an individual does not have a place of business, his or her place of business is deemed to be his or her habitual residence. ${ }^{172}$

The first argument in favour of the claimant is that the provisions of the Act do not apply. Section 20 specifically refers to an interaction between an "individual” and an "electronic agent.” In this case, the individual would be the claimant. The electronic agent would be the authorized lottery computer. Yet, there is no interaction between the individual and the electronic agent. The interaction is first between the claimant, on the one hand, and the authorized agent of the lottery corporation, on the other (with respect to the request for the ticket). Subsequently, there is an interaction between the authorized agent of the lottery corporation, on the one hand, and the authorized lottery computer system as the electronic agent, on the other. Furthermore, the need for direct contact between the individual and the electronic agent is all the more clear when one reviews the opening words of s. 20(3): “A contract formed by the interaction of an individual with the electronic agent of another person has no legal effect and is not enforceable if the individual made a material error in the electronic document." " electronic means if the person had no interaction with the document?

Second, even if (contrary to our assertion above) the ECIA does apply, in our view there is not an error in the ticket such that the ticket should be cancelled pursuant to s. 20(3). First, on the facts, the individual (the claimant) did not make an error. If anything, the electronic agent made an error by pushing the ticket over to the following week's draw prior to the deadline. Second, the contract was formed by the request of the claimant to the attendant, not a request to the information system. ${ }^{174}$ 
Third, even if those arguments are not convincing, the provisions of the Act may in fact help the claimant. There is some issue as to whether an electronic document is formed by "instantaneous communication" or by something more akin to the "postbox" rule. In the former, the contract is deemed to be formed at the time and place that the acceptance is received. ${ }^{175}$ In the latter, the contract is deemed to be formed at the time and place that the acceptance is sent by the offeree. ${ }^{176}$ In the case of lotteries, either could apply. First, a computer system could be equated with either the telephone, ${ }^{177}$ telex, ${ }^{178}$ or the facsimile machine. ${ }^{179}$ Each of these has been found to fall under the instantaneous communication rule. Alternatively, the court could find that the information system through which the contract was formed specifically contemplated a delay between the time of sending and the time of receipt. In such a case, the jurisprudence supports the application of the postbox rule. As was held in Henthorn v. Fraser:

\begin{abstract}
Although the Plaintiff received the offer at the Defendants' office in Liverpool, he resided in another town, and it must have been in contemplation that he would take the offer, which by its terms was to remain open for some days, with him to his place of residence, and those who made the offer must have known that it would be according to the ordinary usages of mankind that if he accepted it he should communicate his acceptance by means of the post. ${ }^{180}$
\end{abstract}

The authors take this to suggest that where one side to the transaction is aware of a specific delay in transmission, over which the other side has no control, the court will generally wish to bind the parties to their bargain as soon as the acceptance has left the control of the party without control over the delay. In this case, the postbox rule would ensure that the acceptance was effective as soon as it was sent from the authorized lottery retailer's terminal.

In the case of electronic documents, the timing of each of these alternatives is dealt with by the ECIA. In terms of when the request was received, s. 21(2)(a) says that it is deemed to be received "when it enters an information system designated or used by the addressee for the purpose of receiving documents of the type sent and is capable of being retrieved and processed by the addressee."181 Interestingly, the paragraph does not provide that receipt occurs "once the document is processed by the information system." Rather, it is a question of when the document "is capable of being retrieved and processed." Quite clearly, once the ticket is printed out, the request has already been processed. Presumably, the processing of the ticket accounts for the ten-second delay that may occur prior to the issuance of the ticket. If this is so, then the ticket is capable of being retrieved and processed by the central computer prior to the issuance of the ticket. Thus, according to the $E C I A,{ }^{182}$ the document

Brinkibon Ltd. v. Stahag Stahl G.m.b.H., [1983] 2 A.C. 34 (H.L.) [Brinkibon]. Household Fire and Carriage Accident Insurance (Limited) v. Grant (1879), 4 Ex.D. 216 (C.A.). Re Modern Fashions Ltd. (1969), 8 D.L.R. (3d) 590 (Man. Q.B.). Brinkibon, supra note 175; Entores Ld. v. Miles Far East Corp., [1955] 2 Q.B. 327 (C.A.). Eastern Power Ltd. v. Azienda Communale Energia and Ambiente (1999), 178 D.L.R. (4th) 409 (Ont. C.A.).

[1892] 2 Ch. 27 at 33 (C.A.). ECIA, supra note 169 .

Ibid. Some may choose to point out that the language of the Act does not specifically refer to "acceptance," one of the keys to contract formation. However, by its reference to "receipt" in s. 21(2), the Act makes clear that it is dealing with formation. When one overlays the common law of contracts on to the Act, receipt of acceptance by the offeror is the last step in contract formation unless the parties specifically agree to delay acceptance. See also Dickinson v. Dodds (1876), 2 Ch.D. 463 (C.A.); Holwell
} 
is both sent and received prior to its processing by the lottery corporation's central computer and, therefore, the contract between the claimant and the lottery corporation, if governed by the Act, would have been formed prior to this point.

\section{B. The Technology Delay Does Not Necessitate a Result IN FAVOUR OF THE LOTTERY CORPORATION}

The lottery corporation will undoubtedly point out that the receipt of the request by the central computer is necessary. ${ }^{183}$ In Quebec, s. 8 of the By-law respecting forecast contests and numbers games provides as follows:

Discrepancy: If there is any discrepancy between a lottery ticket and the data pertaining to that ticket given by the computer of the Company, the latter prevails. ${ }^{184}$

There are four possible responses to this claim. First, the issue here is not one of a discrepancy between the ticket issued, on the one hand, and the central computer, on the other. The question is simply this: when was the contract formed? In other words, taken at face value, the section simply has no application to the facts of the claimant's case because the discrepancy referred to in the legislation has not occurred on these facts.

Second, this approach is neither necessitated by technology nor supported by legislation governing electronic contracts. Ticketmaster can sell out shows by Michael Jackson at a pace of 40,000 tickets an hour, ${ }^{185}$ while the lottery corporation must process each ticket individually, with a delay of up to ten seconds every time. ${ }^{186}$ The lottery corporation controls its own use of technology. It should not be allowed to "hide behind the computer" to its own advantage. ${ }^{187}$

Third, every other lottery corporation in Canada manages to avoid these issues. They do this by providing a "game break" of approximately five to ten minutes before the actual draw deadline. ${ }^{188}$ This allows two things to occur. As soon as the game break is entered into, no new requests for tickets for that night's draw are permitted - the draw is closed and the processing of any last minute or "lightning" ticket requests takes place. ${ }^{189}$ When the draw reopens, ticket requests are for the next lottery draw. Therefore, all participants (the lottery

Securities Ltd. v. Hughes, [1974] 1 All E.R. 161 (C.A.). Therefore, the Act (where it applies) deems the contract to be formed on the date provided for in the Act.

See By-law respecting forecast contests and numbers games, supra note 31, s. 8. See also Loto-Québec Statement of Defence, supra note 10 at para. 40.

See By-law respecting forecast contests and numbers games, ibid.

"Michael Jackson: London concert ticket holders to be refunded say organisers" The Daily Telegraph (27 June 2009), online: Telegraph Media Group <http://www.telegraph.co.uk/culture/music/ michael-jackson/5661942/Michael-Jackson-London-concert-ticket-holders-to-be-refunded-sayorganisers.html>.

See supra note 126 and associated text.

See e.g. Ontario Lottery and Gaming Corporation, Frequently Asked Questions, online: Ontario Lottery and Gaming Corporation <http://www.olg.ca/lotteries/faq.jsp\#22>; Saskatchewan Lotteries, Lottery Ticket Centre Policy Handbook at 7, online: Saskatchewan Lotteries <http://www.sasklotteries.ca/ download/sk/LTCPolicyHandbookSK.pdf.>; Lottery Handbook, supra note 162 at s. 1.3.5; Atlantic Lottery, FAQ's, online: Atlantic Lottery <http://www.alc.ca/FAQs.aspx?type=games>; British Columbia Lotteries Corporation, Lottery Game Guide, online: British Columbia Lotteries Corporation <http:// www.bclc.com/documents/LotteryGuide.pdf> [Game Break policies]. Ibid. 
corporation, the lottery player, and the authorized lotteries retailer) are aware that any tickets purchased after the game break will be for the following draw. However, at the same time, all tickets requested prior to the closing are processed for the draw that was in play when the tickets were requested.

It is also important to note that the technology allows the lottery corporation to know from which authorized retailer the winning ticket was issued. Yet, seemingly, the same technology does not allow the corporation to know when the winning request was made or entered, but only when it was processed. Many people, the authors included, would find such a claim by the lottery corporation difficult to believe.

Finally, if the lottery corporation did know that the request for the winning ticket was made prior to the deadline, and yet the lottery corporation refuses to acknowledge the requested ticket as a winning one, it would seem to be unreasonable on the part of the corporation. Even under the case law which is most favourable to the lottery corporation, unreasonable decision-making is a ground for judicial intervention. ${ }^{190}$ This is all the more problematic when the advertising (controlled by the lottery corporation) refers to a deadline of 9:00 p.m. without any additional reference to, or warning of, a computer delay allegedly necessary as part of the game technology. ${ }^{191}$

\section{Policy Reasons Why the Claimant Should Win}

\section{TRANSPARENCY AND CERTAINTY IN THE LAW}

As described, the courts' interpretation of the lottery regulatory regime in most of the lottery cases to date leaves little scope for nuanced common law arguments. Indeed, the computerized lottery ticket arrangement might well be described as a court sanctioned adhesion contract. The lottery corporation says: "Here is where you can find the rules of the game. You must accept these terms. Take them or leave them.” Because of the aggressive promotional advertising typically employed by lottery corporations, players are taken to know all the rules and regulations of the game, ${ }^{192}$ even when in reality they often do not. ${ }^{193}$

The standard lottery rule requiring the player to prove to the corporation that they hold a winning ticket not only affords a large amount of discretion to the lottery corporation, but has also been interpreted by the courts as casting a very wide net. The case law appears to have interpreted this rule to mean at least two things. First, the lottery player must have a physical manifestation of the ticket. Second, the lottery player must accept the lottery corporation's barrage of self-serving terms and conditions, such as the limitation of liability, among others. As a result, additional principles from the common law of contracts that might otherwise be pertinent to the true nature of the contractual relationship between the parties (such as the details of formation, offer, and acceptance) are funnelled into this framework, glossed over,

$190 \quad$ Murphy (Q.B.), supra note 50.

191 See the discussion of the necessities of technology at supra note 170 and associated text.

192 See Loto-Québec Statement of Defence, supra note 10 at paras. 55-59. See also the failure of "fineprint” arguments in Thierman, supra note 56.

193 It should also be kept in mind that consumers may purposely choose not to read the rules and regulations in order to avoid becoming bound: see Leon E. Trakman, "The Boundaries of Contract Law in Cyberspace” (2009) 2 I.B.L.J. 159. 
and rendered silent, invisible, or irrelevant. Thus, unless a player can show that the lottery corporation acted arbitrarily, unreasonably, or unfairly with respect to the ticket after its creation, ${ }^{194}$ there appears to be little or no chance for success against a lottery corporation if the only line of attack is simple recourse to traditional contract law principles. Indeed, in light of the precedent case law, such a strategy seems doomed to fail.

That being said, it is also equally obvious from the case law that the courts have not adequately articulated when or how the lottery contract is actually formed. In the view of the authors, the formation question is critical to resolving the dispute between the parties, as demonstrated by the common law arguments presented above. To be sure, the loss of chance argument, which the authors believe to be quite compelling, turns on the exact question of formation.

Furthermore, it does not serve the development of the common law of contracts to simply ignore formation of contract issues, particularly when clear opinions on the law of contract in a modern, technological economy are desperately needed. Formation crystallizes the terms of the contract and creates legal rights and obligations between the parties. It carries with it collateral contractual considerations, such as certainty of terms, unilateral changes, and others that can operate in favour of the claimant. Thus, there is a potential conflict because the lottery regulations generally favour the lottery corporation's side of this case. This conflict begs the question: "Do the regulations, as they currently stand, preclude formation of contract arguments and application of collateral contractual principles?” In the view of the authors, they do not.

\section{The Mischief that LotTery Regulations ARe Designed to PREVENT}

Using a reverse causality approach, ${ }^{195}$ the ideal outcome of this case is that the claimant should win half of the jackpot for the draw that he requested. In this case, the claimant deserves to be successful for a number of reasons having little to do with the state of the law and much to do with both the public perception of the lottery corporation and the integrity of the process. However, before we turn our attention to this issue, it is important to identify what we believe is an unspoken policy concern that is pushing the majority of courts down the path that does not recognize these claims.

In the view of the authors, one of the implicit policy assumptions made by the courts when dealing with lottery cases is that no one can claim an absolute right to a win in a lottery prize. There is, hence, reluctance in the courts to provide a remedy. The courts' reliance on a narrow view of the applicable statutory framework and requirements affords the courts the opportunity to avoid having to address the difficulties posed by games of chance in contract law interpretation. ${ }^{196}$ Therefore, when the courts refer to traditional contract doctrine, they tend to haphazardly assert contractual elements to affix the nature of the relationship between the parties, without regard to the implications of the assertions. ${ }^{197}$ 
But if this is the unspoken policy rationale, in the view of the authors it would be beneficial for the courts to make it explicit, if it is to be used at all. To do this, the courts will also be forced to articulate the circumstances under which clear contractual principles must give way to this policy, in addition to clearly articulating how the relevant legislation is to be interpreted.

The authors do not dispute the importance of policy. However, despite the policy considerations put forward by the courts on this point there are equally important countervailing policy implications that should also be considered by the courts in appropriate circumstances. In particular, it is sometimes said that lotteries constitute a voluntary tax on the poor. ${ }^{198}$ For society as a whole to seek to benefit through narrow legalistic doctrines on the backs of some of its most vulnerable members ${ }^{199}$ seems counter to the law's role in protecting, rather than disadvantaging, those who are susceptible to manipulation. There is a need for broader and more generous interpretation, particularly where the state is a singular antagonist that seeks to profit from the actions of its citizens using its own machinery, that is, the courts, to assure itself of that benefit wherever possible. ${ }^{200}$

This is not to say that every person who plays the lottery is vulnerable. Rather, the question becomes one of fundamental fairness. The state controls the lottery offerings available to its citizens through a Crown corporation. It profits from the revenue generated from these activities. It can control, by statute, the rules under which the lottery takes place. Does the state really need further protection in the form of a stream of case law that confuses contract law fundamentals entirely and, as a result, takes a narrow view of the rights of citizens to claim rewards?

In this case, the state cannot even claim a financial reason for its protection. Arguably, the only question is whether one person gets a \$27 million windfall or that windfall is split between two people, both of whom have done everything in their power to play within the lottery game rules, as set by the government. ${ }^{201}$

Charles J. Clotfelter \& Phillip J. Cook, Selling Hope: State Lotteries in America (Cambridge, Mass.: Harvard University Press, 1989) at 215.

199 See e.g. Atlantic Lottery, "Play Responsibly," online: Atlantic Lottery <http://www. alc.ca/English/ResponsibleGaming/>; Manitoba Lotteries Corporation, "Programs and Initiatives," online: Manitoba Lotteries Corporation <http://www.mlc.mb.ca/MLC/content.php?pageid=440\& langdir=E>; Alberta Gaming and Liquor Commission, "Responsible Gambling Program," online: Alberta Gaming and Liquor Commission <http://aglc.ca/responsiblegambling/responsiblegaming program.asp>; Alberta Gaming and Liquor Commission, "Responsible \& Problem Gambling Joint Initiatives," online: Alberta Gaming and Liquor Commission <http://www.aglc.gov.ab.ca/responsible gambling/joint_initiatives.asp>. See also "Retailers must take responsible gambling training" CBC News (25 June 2008), online: CBC News <http://www.cbc.ca/canada/prince-edward-island/story/2008/ 06/26/gambling-course.html>; Ipsos Reid Public Affairs, Final Report: British Columbia Problem Gambling Prevalence Study (Vancouver: Ipsos Reid Public Affairs, 2008), online: British Columbia Partnership for Responsible Gambling < http://www.bcresponsiblegambling.ca/responsible/docs/rpt-rgprevalence-study-2008.pdf $>$; Alberta Alcohol and Drug Abuse Commission, Gambling in Alberta: Policy Background Paper by Darlene James (2003), online: Alberta Health Services <http://www. aadac.com/documents/policy_gambling_background.pdf>.

200 See e.g. Ombudsman Ontario, A Game of Trust by André Marin (Toronto: Ombudsman Ontario, 2007) at 1, 7, online: Ombudsman Ontario <http://www.ombudsman.on.ca/media/3268/a_game_of_trust 26070326.pdf $>$.

201 As a matter of reverse causality, the authors believe that the more equitable result would be the second of these. Also, the discussion of contractual damages for loss of a chance would show that there was no loss suffered by the other winner because the contract between the lottery corporation and the other winner did not specify the right to earn a particular amount. Some might argue that splitting the top prize (between the claimant and the other winner) in these circumstances would be inappropriate. However, 
There is also the issue of the regulations. The lottery corporation will undoubtedly rely on those regulations that specifically refer to (1) the need for central computer involvement, ${ }^{202}$ (2) the need for the player to prove that the ticket was a winning one, ${ }^{203}$ and (3) the discretion granted to the lottery corporation. ${ }^{204}$

In the view of the authors, each of these regulations is aimed at particular types of mischief. For example, the lottery corporation could be inundated with claims if the lottery player was allowed to argue that they believed that the time of purchase was otherwise.

Why would this mischief not apply on these facts? The answer is simple. The agent of the lottery corporation says that this mischief did not occur. There is no disagreement between the corporation, on the one hand (according to the agent of the corporation, the clerk, who was present at the time), and the player, on the other, as to the timing of the event that led to the creation of the contract. This protects the integrity of the game without being unduly restrictive on the lottery player. In the case of any disagreement between the lottery corporation and the lottery player, the regulation provides a tiebreaker.

With respect to the need to prove oneself as a winner, in the view of the authors, the mischief to be avoided is a situation where the lottery corporation is put in the position of having to disprove that every player is a winner. It would take an exceptional amount of effort for the lottery corporation to do this. However, on the facts presented here, the work is both unnecessary (given the testimony of both the agent of the lottery corporation and the claimant) and already done (in the sense that the lottery corporation knows all of the requisite information to declare the claimant a winner). Therefore, the mischief with which the regulation is concerned is not present in this scenario and thus its application is arguably unjustified.

The other mischief that might be at issue is latecomers trying to take advantage of being late. It has occurred that people were able to bet on the outcome of a sporting event after the event had been televised. In this case, again, this type of mischief is not present here. The claimant has done everything in his power to beat the deadline. He is not attempting to gain an unfair advantage by participating late in the lottery. Indeed, the lottery corporation benefits from advertising the ever increasing jackpot prize right up to the last minute,

the other winner does not know at the time he bought the ticket either (1) how many other players will be in the lottery drawing, or (2) the numbers selected by the other players in the lottery. Therefore, there is no contractual claim to the top prize. Instead, the claim of each winner must be that they are entitled to a proportionate share of the top prize along with all other top-prize winners. Therefore, the other winner has no contractual right to claim the whole of the top prize if the claimant was a valid participant: Hardie, supra note 47. Also, the idea of promissory estoppel would not assist the other winner, unless there were some proof offered that there was reasonable reliance by the other winner on some indication that they were the sole winner of the top prize, and some detriment to the winner that would not otherwise have occurred: see John Burrows Ltd. v. Subsurface Surveys Ltd., [1968] S.C.R. 607. By-law respecting forecast contests and numbers games, supra note 31, s. 8.

Interprovincial Lottery Corporation, Rules and Regulations Respecting Lotteries and Lottery Tickets, s. 17, online: Ontario Lottery and Gaming Corporation <http://www.olg.ca/assets/documents/game_ conditions/respecting_tickets.pdf $>$.

Ibid.; By-law respecting forecast contests and numbers games, supra note 31. 
encouraging players to show up just before the deadline. ${ }^{205}$ This is how the game is run by the corporation - to maximize positive results for the corporation. ${ }^{206}$

With respect to the need for discretion, there is no doubt that the lottery corporation needs to make decisions. However, given the statutory and regulatory framework to which the activities of the lottery corporation are subject and the public interest mandate of all Crown corporations, ${ }^{207}$ the question is whether this discretion is being exercised in the public interest. In the view of the authors, it is difficult to make a coherent argument outlining the grounds upon which denying this particular individual a share of the top jackpot prize serves the public interest.

To be granted a monopoly over the public as a party contracting with members of the public is a privilege. It seems to the authors that the enjoyment of such a privilege requires that when the opportunity comes about to protect the public, the corporation must take it. As mentioned earlier, the other lottery corporations across the country have dealt with this problem. ${ }^{208}$ The technology exists to avoid this issue. Loto-Québec has chosen thus far not to implement this protection and follow the standard that has been set by other lottery corporations. Yet, in essence, it still asserts that its failure to do so is somehow in the public interest and the mischief that arises from its failure is the fault of the claimant. ${ }^{209}$ The Court in Ifergan has the opportunity to encourage the government to exercise its monopoly in a responsible way by holding that its failure in this regard is compensable when it causes a loss in a scenario like the one that has occurred with respect to the claimant.

Finally, the law has already held that if a computer error shows a payment to a participant that is greater than that to which the participant is contractually entitled, the law of contract will hold that the participant is entitled to the lower amount, despite the computer error. ${ }^{210}$ Yet, if the computer is unable to process the contract at the time when it was completed, according to Loto-Québec's defence, the player must live with that result. So, according to the case law already referred to, if the computer gives the participant too much, the law of contract will protect the lottery corporation. ${ }^{211}$ If, on the other hand, the computer gives the participant no chance to receive what was bargained for, the law (according to Loto-Québec at least) will protect the lottery corporation. While this result would certainly serve the purposes of the lottery corporation, it seems clear that this would be inequitable as a matter of policy. ${ }^{212}$

The regulatory framework is clearly important in lotteries. However, it is not a comprehensive code. The very reliance on contractual principles in the cases discussed in

See supra note 93 and associated text.

See e.g. Canada Business Corporations Act, R.S.C. 1985, c. C-44, ss. 15(1), 122; Peoples Department Stores Inc. (Trustee of) v. Wise, 2004 SCC 68, [2004] 3 S.C.R. 461; BCE Inc. v. 1976 Debentureholders, 2008 SCC 69, [2008] 3 S.C.R. 560.

See sources referred to at supra note 199. See also Marin, supra note 200.

See sources referred to at supra note 188.

Loto-Québec Statement of Defence, supra note 10 at paras. 60-61.

Budai, supra note 36.

Ibid. Admittedly, Budai provided a misrepresentation based remedy, but denied contractual damages. It is true that Sullivan, supra note 41, makes reference to the possibility of the awarding of damages for the infliction of mental shock. However, this is only a theoretical possibility, as the Court in Sullivan declined to award damages for the infliction of mental shock on the facts of the case. Therefore, the statement on this subject in the Sullivan case is, at best, of limited precedential value. 
this article conclusively demonstrates this. Where the boundaries of the regulatory framework do not seem appropriate to the circumstances, the common law can and, in the view of the authors, should be used to supplement ambiguities in the regulatory framework, and define when it would be insufficient to address the particular circumstances solely within the confines of that framework. In the view of the authors, in the claimant's circumstances, the framework both (1) contains sufficient ambiguities to be supplemented by the law of contracts; and (2) is insufficient for these particular circumstances.

\section{CONCLUSION}

In the end, the authors acknowledge that there are valid arguments on both sides of the issue of disputed lottery awards. An overly broad application of the regulatory framework tends to favour the lottery corporation. However, the application of contractual principles (on which many of the lottery cases reviewed purport to rely) shifts the focus to formation, the intention of the parties, and legally binding consideration. In the few cases where there is more than a superficial analysis of the contractual elements of the relationship between the lottery player and the lottery corporation, these elements are more likely to favour the lottery player. This is true whether the lottery player is viewed as either the offeree (the view of the authors) or the offeror (the allegation of the lottery corporation in its pleadings).

In the view of the authors, the regulatory framework does not necessarily preclude the acceptance of any of these arguments. If this is so, then the matter also turns on issues of public policy and statutory interpretation. As set out above, there are conflicting public policy concerns. However, the weight of these concerns favours the player, given that the lottery corporation has a degree of control over the statutory and regulatory framework that governs all lotteries.

Ultimately, however, the fantastic story being told here is the age-old adage that timing is everything. So the question for the Court charged with resolving this intriguing dispute is, "who should be held to bear the burden for this folly, Joel Ifergan or Loto-Québec?" 